Article

\title{
Geochemistry and Petrogenesis of Shoshonitic Dyke Swarm in the Northeast of Meshkinshahr, NW Iran
}

\author{
Mohammad Fadaeian ${ }^{1}\left(\mathbb{C}\right.$, Ahmad Jahangiri ${ }^{2}$, , Songjian Ao ${ }^{3, *}$, Amin Allah Kamali ${ }^{4}$ and Wenjiao Xiao ${ }^{3(\mathbb{C}}$ \\ 1 Department of Geology, Payame Noor University, Tehran 19395, Iran; m_fadaeyan@pnu.ac.ir \\ 2 Department of Geology, University of Tabriz, Tabriz 51664, Iran; a_jahangiri@tabrizu.ac.ir \\ 3 State Key Laboratory of Lithospheric Evolution, Institute of Geology and Geophysics, Chinese Academy of \\ Sciences, Beijing 100029, China; wj-xiao@mail.iggcas.ac.cn \\ 4 Research Center for Conservation of Culture Relics (RCCCR), Research Institute of Cultural Heritage and \\ Tourism, Tehran 11456, Iran; aminkamali1984@gmail.com \\ * Correspondence: asj@mail.iggcas.ac.cn
}

check for updates

Citation: Fadaeian, M.; Jahangiri, A.; Ao, S.; Kamali, A.A.; Xiao, W. Geochemistry and Petrogenesis of Shoshonitic Dyke Swarm in the Northeast of Meshkinshahr, NW Iran. Minerals 2022, 12, 309. https:// doi.org/10.3390/min12030309

Academic Editor: Ryan Mathur

Received: 5 November 2021

Accepted: 23 February 2022

Published: 28 February 2022

Publisher's Note: MDPI stays neutral with regard to jurisdictional claims in published maps and institutional affiliations.

Copyright: (C) 2022 by the authors. Licensee MDPI, Basel, Switzerland. This article is an open access article distributed under the terms and conditions of the Creative Commons Attribution (CC BY) license (https:// creativecommons.org/licenses/by/ $4.0 /)$.

\begin{abstract}
The study area is located in Ardabil province in the northeast of Meshkinshahr city. More than 200 small and large Eocene-age dykes form outcrops in this area. Laser ablation-inductively coupled plasma-mass spectrometry (LA-ICP-MS) U-Pb zircon analyses yield a consistent age of $44.3 \pm 1.8 \mathrm{Ma}$ for the dyke swarms. These dykes include tephritic, andesitic and basaltic compositions, and show enrichment in LREEs (relative to HREEs) and are characterized by enrichment in LILEs and depletion in HFSEs. Petrological observations, along with major, rare earth and trace elements geochemistry, suggest that the dykes have a shoshonitic signature. All the rocks are highly enriched in incompatible trace elements and have variable $\mathrm{Sr}-\mathrm{Nd}$ isotopes. Enrichment in incompatible elements and other geochemical features for the dyke swarm rocks suggest that a metasomatized subcontinental lithospheric mantle is the magma source. The negative $\mathrm{Nb}-\mathrm{Ta}-\mathrm{Ti}$ anomalies in the rocks are comparable with the features of subduction-related magmatism and contamination with ancient crustal components. The radiogenic ${ }^{87} \mathrm{Sr} /{ }^{86} \mathrm{Sr}$ isotopic values of the rocks imply the involvement of slab terrigenous sediments and/or a continental lithosphere. Isotopically, the volcanic rocks exhibit a binary trend, representing $1-5 \%$ mixing between the primary mantle and sediment melts. Our melting models suggest that there are residual garnet + spinel in the source, which are incompatible with the partial melting of amphibole- and/or phlogopite-bearing lherzolites. The geochronological, geochemical and isotopic data for the northeast Meshkinshahr dyke swarms suggest that these Late Eocene magmas were derived from a small degree of partial melting of a subduction-metasomatized lithospheric mantle source in a post-collisional setting.
\end{abstract}

Keywords: dyke swarms; geochemistry; shoshonite; $\mathrm{Sr}-\mathrm{Nd}$ isotope; U-Pb zircon dating; post collisional magmatism; Iran

\section{Introduction}

Our understanding of dyke emplacement mechanisms is important, as dykes are feeders of volcanic eruption in which magmatic evolution take place. Crust-mantle interaction plays a significant role in the delineation of crustal provinces, as well as in deciphering crustal evolution events [1-3]. Shoshonitic rocks generally show $\mathrm{SiO}_{2}$ at less than $70 \mathrm{wt}$. percentage [4]. On the other hand, [5] suggested that shoshonites should also include more silicic rocks, such as dacite and rhyolite. The authors only regarded volcanic rock types with $\mathrm{SiO}_{2}<63$ wt. percentage as shoshonites [6]. Shoshonites can be subdivided into basic $\left(\mathrm{SiO}_{2}<53\right.$ wt.\%), intermediate $\left(\mathrm{SiO}_{2}=53-63 \mathrm{wt} . \%\right)$ and silicic $\left(\mathrm{SiO}_{2}>63 \mathrm{wt} . \%\right)$ types [7]. The origin of shoshonitic suites is a point of debate [8]. It seems that the chemical variability of shoshonitic rocks is not completely understood in terms of source characteristics and geodynamic setting. Shoshonites are restricted to subduction-related tectonic settings, where they were generated during the late stage of arc evolution, typically after the low-K 
tholeiites and calc-alkaline rock series [7]. Similarly, [9] concluded that shoshonites should be regarded as products of the magmatic activity above the subduction zones in continental arcs, post-collisional arcs or in oceanic arc settings. Most shoshonites form in a convergent continental setting, normally in association with subduction [10]. It has been suggested that they were formed by the partial melting of the lower crust, following underplating by mantle-derived magma [11,12]. The metasomatic hypothesis for the origin of shoshonites is consistent with the experimental work of [13], who showed that potassic magmas can be produced by the melting hydrated mantle. In the Anatolia, the Caucasus and northwest Iran, the Eocene epoch is characterized by widespread basic to acidic magmatism, whose temporal and spatial evolutions and origin are poorly understood [14]. Cenozoic volcanic rocks in Iran include Paleogene, Miocene and Plio-Quaternary sequences, which occur mainly in Central Iran (Urumieh-Dokhtar magmatic belt), the Alborz-Azerbaijan mountains, and the northern Lut Block (Figure 1). Paleogene volcanic and associated volcano-sedimentary rocks are extensive and blanket vast areas with kilometer-scale thickness. Marine fossils within the Paleogene pyroclastic sequence, such as nummulitic green tuffs, indicate that volcanism was largely shallow marine (e.g., $[15,16])$. The cause of Paleogene volcanism has been, in general, a matter of controversy for three decades. The linear trend of Urumieh-Dokhtar magmatic belt (UDMB) parallel to the Arabia-Eurasia suture and Sanandaj-Sirjan metamorphic zone (Figure 1), the subduction signature trace element characteristics of Paleogene volcanism and the steady northward motion of the northern Arabian margin from an initial position $>1300 \mathrm{~km}$ south of the present-day suture [17] have led to the dominant opinion that the Urumieh-Dokhtar belt is a conventional active margin continental arc analogous to the Andes (e.g., [16,18]). In contrast, [19], "based on" major element data from alkaline Tertiary volcanic rocks, proposed that the Urumieh-Dokhtar belt is unrelated to the subduction environment and is a linear rift basin. The geochemical and intensity variation of volcanism related to Neotethyan oceanic subduction from the Cretaceous to Miocene interval led [20] to the change in Benioff zone geometry and the plates' convergence rate. Meanwhile, these authors stated that extensive volcanic activity in the Paleogene occurred due to flattening subduction and accompanied extension and flare-up volcanism due to slab rollback. On the other hand, the closure time of the Neotethys Ocean and the estimation of the collision time of Eurasia and the Arabian plate is controversial, and the age of the Arabia-Eurasia collision has been estimated to range from the Late Cretaceous to Pliocene (e.g., [17,18,21]).

Paleocene volcanic rocks with shoshonitic affinity, including trachy-andesite, tephrite and basanitic rocks, mainly crop out in the Azerbaijan-Alborz-Sabzevar zone, specifically in the Ahar-Arasbaran volcanic belt and northeast of Meshkinshahr in NW Iran (which is the study area) [21-30]. The Paleocene magmatism in the Urumieh-Dokhtar magmatic belt and south of the Anatolian block is calc-alkalic to shoshonitic, which resulted from the subduction of the Neotethys Ocean beneath the central Iranian and Anatolian blocks [25,31-37]. The Eocene shoshonitic volcanism in northern Iran extends into the Central Iranian volcanic belt along a NW-SE trending linear zone. This volcanic belt contains lower Eocene-age basalts, trachybasalts, trachyandesites and volcanic bereccia in the Meshkinshahr to QomAran area in its northern segment $[19,38]$, slightly more evolved shoshonites composed of middle to upper Eocene shoshonitic swarm dykes in the northeast of Meshkinshahr [39] and basaltic lavas, tephrites, phonolites and tephrite phonolites in the Natanz-Nain and Shahrebabak areas in its central parts $[40,41]$. Upper Eocene trachybasalts and trachyandesites occur in the Rafsanjan area [42], and analcime-rich pyroclastic rocks crop out in the Bardsir area [43] in the southern end of the belt. The present study is focused on the petrography and mineral chemistry, whole rock geochemistry and $\mathrm{Sr}-\mathrm{Nd}$ isotope composition of a shoshonitic dyke swarm located in the northwest of Iran. Our aim is to shed more light on their petrogenesis and to better understand the composition of the mantle wedge involved in Neotethys subduction, and the composition of their mantle source(s) and their possible interaction with the crustal material are discussed. The study of the magmatic 
features of the dyke swarm could help us narrow down the magmatic-tectonic processes acting during the Paleocene and governing lithospheric evolution in the NW of Iran [44].

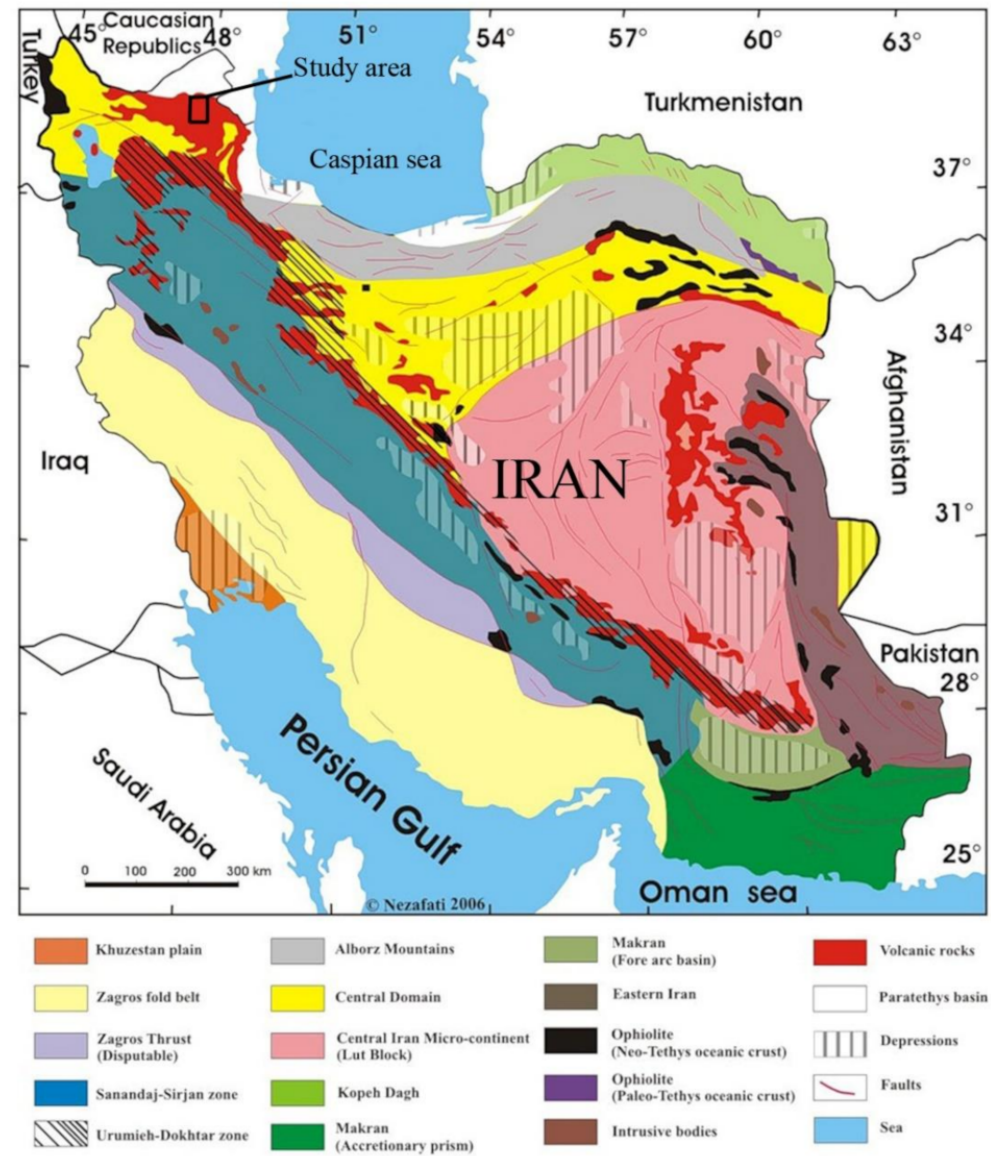

Figure 1. Tectonic scheme of Iran with the main tectonic subdivisions, modified after $[15,45,46]$ and publications of the Geological Survey of Iran [47].

\section{Geological Setting}

Cenozoic volcanism in Iran can be studied in three areas: (a) the Alborz volcanic belt, running in the north of Iran with E-W trending, which extends to the east, up to the Iran-Afghanistan border, and west, extending to the Lesser Caucasus; (b) the Central Iranian volcanic belt, running across Central Iran for about $1800 \mathrm{~km}$ in the NW-SE direction, roughly parallel to the Zagros trend and some 150-200 km from the main Zagros thrust to the northeast of it (known as the Urumieh-Dokhtar magmatic belt UDMA); (c) the Lut Block (Eastern Iran) volcanic province. The Alborz and Central Iranian volcanic belts join in Turkey in the Van Lake area (Eastern Anatolia) and the volcanic Lesser Caucasus (Figure 1). Volcanism in Iran is well represented from the Eocene to sub-recent times, but the main volcanic phases took place in the Eocene-Oligocene and Upper Miocene to Pliocene-Quaternary, whereas most intrusive rocks belong probably to the Oligocene [15]. Unfortunately, data on this widespread and impressive volcanism are scarce. A large, young volcanic province roughly located between the Caspian Sea and the Black Sea, extending westwards into central Anatolia, is thereby formed (with volcanism in Azerbaijan). The study area is part of this major province, and has witnessed varied and protracted volcanic activity, which can be separated into various stages, since at least the Paleogene and up to recent times [48] (Figure 1). The first studies of stratigraphy and the geological evolution of the investigated area were conducted by [49]. The oldest rock units in this area are a sequence of pelagic Cretaceous limestones with intercalations of shale and cherts accompanied with spilitic basaltic lavas that are exposed in the NW of the studied area [50] (Figure 2). The Cretaceous sequence was folded during the Upper Cretaceous 
and is covered uncomfortably by Paleogene volcanic and pyroclastic units. The Paleogene sequence was initiated by the alternation of shale, tuffaceous sandstones and brecciated volcanic rocks with hyaloclastic and tuff cements. This unit was cut when Eocene volcanism started and reached its climax probably during the Middle and Upper Eocene [49]. The composition of igneous rocks includes tephrite, leucite-tephritic and basanitic rocks with pyroclastic interlayers. The study area covers a large part of the collection of Eocene igneous rocks (Figure 2) [50]. The isotopic age available up to now [51] gives values from 43 to $38 \mathrm{my}$, and would place the cycle at the transition period between Eocene and Oligocene. The tectonic activity, which took place at different stages in the Tertiary and Quaternary, was mainly tensional. Faulted blocks were sometimes strongly tilted, and the faulted escarpments, up to some hundred meters high, together with differential erosion, gave rise to the rugged out-lines of some districts, especially in the northwestern part of the plateau. Dykes are distributed across the whole of the study area, and they show variable strikes; in spite of a high number of measurements, the dispersion value was such that significant frequency maxima did not emerge. They are vertical to sub-vertical, up to some kilometers long and from some decimeters to a few meters thick. Over 300 small and large dykes with thicknesses of 1-20 m are exposed in the NE of the Meshkinshahr district, covering an area of about $40 \mathrm{~km}^{2}$ (Figure 3). They are dominantly oriented in a NNE-SSW strike and intruded into the Lower Eocene volcanic breccias [50]. In the Upper Oligocene, block faulting developed and subsidence took place in the Meshkinshahr basin, where limited marine to lagoonal sediments were deposited in the Miocene times, separating the northwestern area of the plateau from the southeastern one [50].

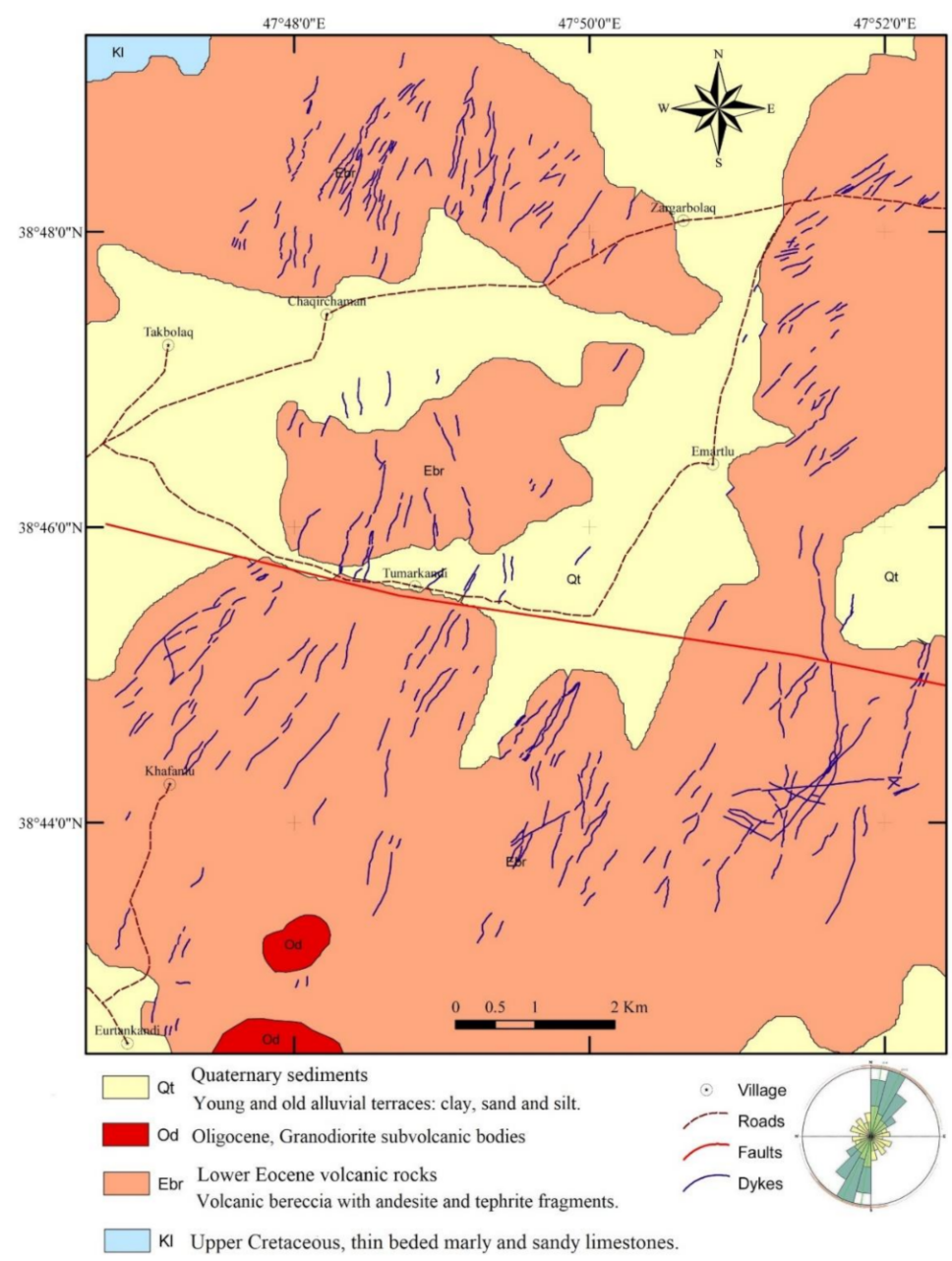

Figure 2. Geological map of the northeast of the Meshkinshahr [50] and present work on the distribution of mafic dyke swarms is shown. 

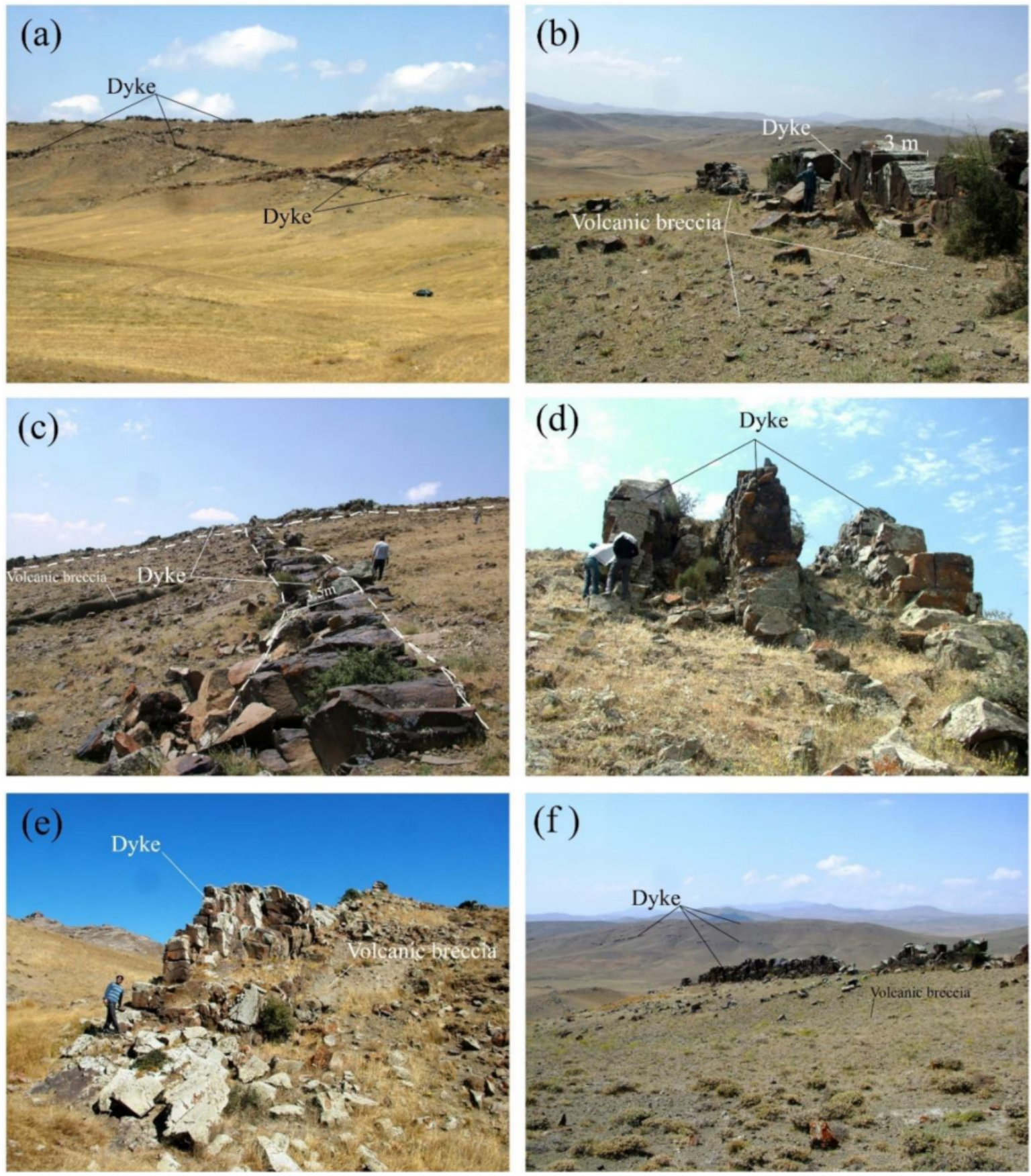

Figure 3. Outcrop photos of dykes and their host volcanic breccia. (a) Crossed tephritic dykes intruded into the north of the study area. (b) A basaltic dyke intruded in the volcanic breccia in the west of the study area. (c) A NE-SW tephritic dyke cuts across a NW-SE dyke in the east of study area. (d) Three tephritic dykes intruded in the volcanic breccia with along a parallel NW-SE strike. (e) An andesitic dyke with a width of $5 \mathrm{~m}$ in the northern region. (f) Some tephritic and basaltic dykes that outcrop in the study area.

\section{Materials and Methods}

During field studies, approximately 200 samples were collected and, after thin section petrographic studies, some of the unaltered samples were selected for analysis. Then, 41 whole-rock samples were analyzed for major and trace elements and REE. Whole-rock major elements were determined on fused glass disks using a Phillips PW1500 X-ray fluorescence spectrometer at the Institute of Geology and Geophysics, Chinese Academy of Sciences (IGGCAS), Beijing. The analytical precision is better than \pm 5 percent, estimated 
from repeated analyses of the Chinese whole-rock andesite reference sample GSR-2. Trace element contents were measured on a Finnigan MAT Element mass spectrometer (ICP-MS) at IGGCAS after complete dissolution. Powders $(\sim 40 \mathrm{mg})$ were dissolved in distilled $\mathrm{HF}+\mathrm{HNO}_{3}$ in $15 \mathrm{~mL}$ Savillex Teflon screw-cap beakers at $200{ }^{\circ} \mathrm{C}$ for five days, dried and then diluted to $50 \mathrm{~mL}$ for analysis. Indium was used as an internal reference sample to correct for matrix effects and instrument drift. Precision for all trace elements is estimated to be \pm 5 percentage, and accuracy is better than \pm 5 percent for most elements according to the analyses of the GSR-2 reference sample.

The $\mathrm{Rb}-\mathrm{Sr}$ and $\mathrm{Sm}-\mathrm{Nd}$ isotopic analysis (Table 2) followed procedures similar to those described by [52]. Whole-rock powders for $\mathrm{Sr}$ and $\mathrm{Nd}$ isotopic analyses were dissolved in Savillex Teflon screw-top capsules after being spiked with the mixed ${ }^{87} \mathrm{Rb}-{ }^{84} \mathrm{Sr}$ and ${ }^{149} \mathrm{Sm}-{ }^{150} \mathrm{Nd}$ tracers prior to $\mathrm{HF}+\mathrm{HNO}_{3}+\mathrm{HClO}_{4}$ dissolution. $\mathrm{Rb}, \mathrm{Sr}$, Sm and $\mathrm{Nd}$ were separated using the classical two-step ion exchange chromatographic method and measured using a Thermo Fisher Scientific Triton Plus multi-collector thermal ionization mass spectrometer (TIMS) at IGGCAS. The whole procedure blank was lower than $250 \mathrm{pg}$. for $\mathrm{Rb}-\mathrm{Sr}$ and $100 \mathrm{pg}$. for $\mathrm{Sm}-\mathrm{Nd}$. The isotopic ratios were corrected for mass fractionation by normalizing them to ${ }^{88} \mathrm{Sr} /{ }^{86} \mathrm{Sr}=8.375209$ and ${ }^{146} \mathrm{Nd} /{ }^{144} \mathrm{Nd}=0.7219$, respectively. The international reference sample samples, NBS-987 and JNdi-1, were employed to evaluate instrument stability during the period of data collection. The measured values for the NBS-987 Sr reference sample and JNdi-1 Nd reference sample were ${ }^{87} \mathrm{Sr} /{ }^{86} \mathrm{Sr}=0.710245 \pm 0.000021(n=9,2 \mathrm{SD})$ and ${ }^{143} \mathrm{Nd} /{ }^{14} 4 \mathrm{Nd}=0.512111 \pm 0.000012$ $(n=9,2 \mathrm{SD})$, respectively. USGS reference material BCR-2 was measured to monitor the accuracy of the analytical procedures, with the following results: ${ }^{87} \mathrm{Sr} /{ }^{86} \mathrm{Sr}=0.705025$ \pm 0.000013 and ${ }^{143} \mathrm{Nd} /{ }^{144} \mathrm{Nd}=0.512621 \pm 0.000010$. The ${ }^{87} \mathrm{Sr} /{ }^{86} \mathrm{Sr}$ and ${ }^{143} \mathrm{Nd} /{ }^{144} \mathrm{Nd}$ data of BCR-2 show good agreement with previously published data by TIMS technique $[52,53]$.

Following this, 22 samples for $\mathrm{U}-\mathrm{Pb}$ analyses were processed using conventional magnetic and density techniques to concentrate non-magnetic heavy fractions. Zircon grains, together with zircon reference sample 91500, were mounted in epoxy mounts, which were then polished to section for analysis. All zircons were documented with transmitted and reflected light micrographs, as well as cathodoluminescence (CL) images, to reveal their internal structures, and the mount was vacuum-coated with high-purity gold prior to secondary ion mass spectrometry (SIMS) and laser ablation inductively coupled plasma mass spectrometry (LA-ICP-MS) analyses at the Institute of Geology and Geophysics, Chinese Academy of Sciences (IGGCAS) in Beijing. The samples were dated via LA-ICPMS at IGGCAS, using an Agilent 7500a quadruple ICPMS and a Thermo-Finnigan Neptune multi-collector ICPMS connected to a $193 \mathrm{~nm}$ Excimer ArF laser-ablation system (Geolas plus). The analyses were carried out with a beam diameter of $32 \mathrm{um}$ and a $6 \mathrm{~Hz}$ repetition rate, and the ablation depth was $20-40 \mu \mathrm{m}$. Helium was used as a carrier gas to enhance the transport efficiency of the ablated material. The Harvard zircon 91500 was used as the external reference sample for age calculation, and the Australian National University zircon NIST SRM 610 was used as the external reference sample for concentration calculations. The detailed analytical procedures for LA-ICP-MS can be found in [54]. Common lead was corrected for LA-ICP-MS results using the correction proposed by [55]. The weighted mean $\mathrm{U}-\mathrm{Pb}$ ages and Concordia plots were carried out using the Isoplot/Ex v. 3.00 programs [56] (Table 3).

\section{Results}

\subsection{Petrographic Description}

The petrographic description of the studied dykes is summarized below. They can be subdivided into the following four main groups, for which a nomenclature largely "based on" chemical data (see Table 1) has been used: Tephritic dykes; Andesitic dykes; Basaltic dykes. 
Table 1. Whole-rock major oxides (wt.\%) and trace elements (ppm) of dyke swarms.

\begin{tabular}{|c|c|c|c|c|}
\hline Rock Type & & & & \\
\hline $\begin{array}{c}\text { Sample } \\
\text { No. }\end{array}$ & Dy-17 & Dy-27 & Dy-38 & Dy-43 \\
\hline $\mathrm{SiO}_{2}$ & 50.20 & 49.40 & 50.40 & 49.50 \\
\hline $\mathrm{TiO}_{2}$ & 0.88 & 0.68 & 0.78 & 0.76 \\
\hline $\begin{array}{ll}\mathrm{Al}_{2} \mathrm{O}_{3} \\
\end{array}$ & $\begin{array}{l}0.00 \\
16.25\end{array}$ & 14.80 & 14.55 & 15.15 \\
\hline $\begin{array}{l}\mathrm{Al}_{2} \mathrm{O}_{3} \\
\mathrm{Fe}_{2} \mathrm{O}_{3}\end{array}$ & $\begin{array}{l}10.25 \\
9.72\end{array}$ & $\begin{array}{l}14.80 \\
9.39\end{array}$ & $\begin{array}{l}14.03 \\
9.60\end{array}$ & $\begin{array}{l}13.15 \\
10.09\end{array}$ \\
\hline $\mathrm{MnO}$ & 0.16 & 0.16 & 0.15 & 0.17 \\
\hline $\mathrm{MgO}$ & 4.22 & 5.06 & 5.36 & 5.13 \\
\hline $\mathrm{CaO}$ & 8.03 & 9.24 & 9.43 & 8.66 \\
\hline $\mathrm{Na}_{2} \mathrm{O}$ & 3.15 & 2.62 & 2.71 & $\begin{array}{l}0.00 \\
2.65\end{array}$ \\
\hline $\mathrm{K}_{2} \mathrm{O}$ & $\begin{array}{l}3.13 \\
4.44\end{array}$ & $\begin{array}{l}.202 \\
4.74\end{array}$ & 4.28 & $\begin{array}{l}2.03 \\
4.84\end{array}$ \\
\hline $\mathrm{P}_{2} \mathrm{O}_{5}$ & 0.43 & 0.47 & 0.47 & 0.54 \\
\hline $\mathrm{Cr}_{2} \mathrm{O}_{3}$ & 0.01 & 0.01 & 0.01 & 0.01 \\
\hline $\mathrm{BaO}$ & 0.14 & 0.13 & 0.11 & 0.12 \\
\hline $\mathrm{SO}_{3}$ & 0.05 & 0.04 & 0.04 & 0.03 \\
\hline SrO & 0.10 & 0.12 & 0.11 & 0.14 \\
\hline LOI_1000 & $\begin{array}{l}1.69 \\
1.69\end{array}$ & 2.64 & 1.95 & $\begin{array}{l}.187 \\
1.87\end{array}$ \\
\hline Total & 99.47 & 99.50 & 99.95 & 99.66 \\
\hline $\mathrm{FeO}^{t}$ & 8.75 & 8.45 & 8.64 & 9.08 \\
\hline Mg\# & 46.24 & 51.63 & 52.52 & 50.18 \\
\hline$\underset{K_{2} \mathrm{O}}{\mathrm{Na}_{2} \mathrm{O}}+$ & 7.59 & 7.36 & 6.99 & 7.49 \\
\hline $\mathrm{Na}_{2} \mathrm{O} / \mathrm{K}_{2} \mathrm{O}$ & 0.71 & 0.55 & 0.63 & 0.55 \\
\hline Trace & & & & \\
\hline $\mathrm{Ba}$ & 1235.00 & 1210.00 & 975.00 & 1005.00 \\
\hline $\mathrm{Ce}$ & 62.70 & 57.40 & 60.80 & 65.90 \\
\hline $\mathrm{Cr}$ & 20.00 & 60.00 & 70.00 & 70.00 \\
\hline Cs & 20.30 & 1.74 & 1.94 & 10.00 \\
\hline Dy & 4.90 & 4.07 & 4.65 & 4.28 \\
\hline $\mathrm{Er}$ & 2.56 & 2.22 & 2.29 & 1.95 \\
\hline $\mathrm{Eu}$ & 1.44 & 1.57 & 1.76 & 1.53 \\
\hline $\mathrm{Ga}$ & 19.30 & 16.60 & 17.30 & 16.40 \\
\hline $\mathrm{Gd}$ & 5.59 & $\begin{array}{l}5.73 \\
5.73\end{array}$ & 6.03 & $\begin{array}{l}10.40 \\
5.33\end{array}$ \\
\hline $\begin{array}{l}\mathrm{Gd} \\
\mathrm{Hf}\end{array}$ & $\begin{array}{l}5.59 \\
3.90\end{array}$ & $\begin{array}{l}5.73 \\
2.90\end{array}$ & $\begin{array}{l}6.03 \\
3.20\end{array}$ & $\begin{array}{l}5.33 \\
3.20\end{array}$ \\
\hline Ho & 0.94 & 0.80 & 0.86 & 0.76 \\
\hline $\mathrm{La}$ & 33.80 & 31.70 & 32.20 & 35.40 \\
\hline $\begin{array}{l}\mathrm{La} \\
\mathrm{Lu}\end{array}$ & 0.32 & 0.27 & 0.28 & 0.31 \\
\hline $\mathrm{Nb}$ & $\begin{array}{l}0.32 \\
9.40\end{array}$ & 5.40 & $\begin{array}{l}6.20 \\
6.50\end{array}$ & $\begin{array}{l}0.51 \\
7.70\end{array}$ \\
\hline $\mathrm{Nd}$ & 32.10 & $\begin{array}{l}29.80 \\
29.80\end{array}$ & $\begin{array}{l}0.30 \\
32.20\end{array}$ & 32.90 \\
\hline $\mathrm{Pr}$ & 7.96 & 7.49 & 8.14 & 8.52 \\
\hline $\mathrm{Rb}$ & 100.00 & 96.80 & 94.90 & 112.50 \\
\hline $\mathrm{Sm}$ & 6.77 & $\begin{array}{l}6.54 \\
6.54\end{array}$ & 7.24 & 7.32 \\
\hline $\mathrm{Sn}$ & 2.00 & $\begin{array}{l}0.34 \\
1.00\end{array}$ & 2.00 & 2.00 \\
\hline $\mathrm{Sr}$ & 823.00 & 1010.00 & 946.00 & 1095.00 \\
\hline $\mathrm{Ta}$ & 0.70 & 0.40 & 0.60 & 0.50 \\
\hline $\mathrm{Tb}$ & 0.76 & 0.77 & 0.80 & 0.77 \\
\hline Th & 9.87 & 8.43 & 8.33 & 9.02 \\
\hline $\mathrm{Tm}$ & 0.34 & $\begin{array}{l}0.43 \\
0.31\end{array}$ & $\begin{array}{l}0.30 \\
0.33\end{array}$ & 0.31 \\
\hline $\mathrm{U}$ & $\begin{array}{l}0.54 \\
2.49\end{array}$ & 2.41 & 2.39 & 2.25 \\
\hline $\mathrm{V}$ & 280.00 & 271.00 & 272.00 & 253.00 \\
\hline W & 5.00 & 3.00 & 2.00 & 2.00 \\
\hline $\mathrm{Y}$ & 24.20 & 19.90 & 22.70 & 20.50 \\
\hline $\mathrm{Yb}$ & 2.30 & 1.87 & 2.24 & 2.06 \\
\hline $\mathrm{Zr}$ & 134.00 & 99.00 & 108.00 & 113.00 \\
\hline $\mathrm{Ag}$ & 0.25 & 0.25 & 0.25 & 0.25 \\
\hline As & 5.00 & 5.00 & 6.00 & \\
\hline $\mathrm{Cd}$ & 0.25 & 0.25 & 0.25 & 0.25 \\
\hline $\mathrm{Co}$ & 27.00 & 30.00 & 29.00 & 30.00 \\
\hline $\mathrm{Cu}$ & 127.00 & 129.00 & 110.00 & 125.00 \\
\hline $\mathrm{Li}$ & 20.00 & 10.00 & 10.00 & 20.00 \\
\hline Mo & 1.00 & 2.00 & 1.00 & 1.00 \\
\hline $\mathrm{Ni}$ & 14.00 & 21.00 & 25.00 & 24.00 \\
\hline $\mathrm{Pb}$ & 18.00 & 15.00 & 19.00 & 16.00 \\
\hline $\mathrm{Sc}$ & 23.00 & 28.00 & 30.00 & 26.00 \\
\hline Zn & 86.00 & 80.00 & 76.00 & 87.00 \\
\hline Sum_REE & 162.48 & 150.54 & 159.82 & 167.34 \\
\hline $\mathrm{Dy} / \mathrm{Dy}$ * & 0.68 & 0.66 & 0.66 & 0.63 \\
\hline $\mathrm{Dy} / \mathrm{Yb}$ & 2.13 & 2.18 & 2.08 & 2.08 \\
\hline $\mathrm{Eu} / \mathrm{Eu}^{*}$ & 0.72 & 0.79 & 0.82 & 0.75 \\
\hline $\mathrm{Th} / \mathrm{Hf}$ & 2.53 & 2.91 & 2.60 & 2.82 \\
\hline$(\mathrm{Ce} / \mathrm{Yb})_{\mathrm{N}}$ & 6.93 & 7.81 & 6.90 & 8.14 \\
\hline$(\mathrm{La} / \mathrm{Sm})_{\mathrm{N}}$ & 3.071 & 2.982 & 2.736 & 2.975 \\
\hline$(\mathrm{Sm} / \mathrm{Yb})_{\mathrm{N}}$ & 3.19 & 3.79 & 3.50 & 3.85 \\
\hline Rock type & Andesite & & & \\
\hline Sample No. & Dy-93 & Dy-20 & Dy-29 & Dy-31 \\
\hline $\mathrm{SiO}_{2}$ & 49.20 & 49.20 & 48.10 & 47.10 \\
\hline $\mathrm{TiO}_{2}$ & 0.98 & 0.87 & 0.75 & 0.71 \\
\hline $\mathrm{Al}_{2} \mathrm{O}_{3}$ & 16.95 & 18.05 & 14.75 & 14.20 \\
\hline $\mathrm{Fe}_{2} \mathrm{O}_{3}$ & 7.76 & 9.79 & 10.02 & 10.18 \\
\hline $\mathrm{MnO}$ & 0.16 & 0.19 & 0.18 & 0.18 \\
\hline $\mathrm{MgO}$ & $\begin{array}{l}3.10 \\
3.00\end{array}$ & 4.26 & 5.19 & 5.18 \\
\hline $\mathrm{CaO}$ & 7.58 & 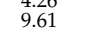 & $\begin{array}{l}0.19 \\
10.40\end{array}$ & $\begin{array}{l}5.18 \\
11.55\end{array}$ \\
\hline $\mathrm{Na}_{2} \mathrm{O}$ & 1.62 & 2.86 & 2.21 & 1.04 \\
\hline $\mathrm{K}_{2} \mathrm{O}$ & 3.86 & 2.83 & 4.47 & 5.48 \\
\hline $\mathrm{P}_{2} \mathrm{O}_{5}$ & 0.60 & 0.44 & 0.54 & 0.55 \\
\hline $\mathrm{Cr}_{2} \mathrm{O}_{3}$ & 0.01 & 0.01 & 0.01 & 0.01 \\
\hline $\mathrm{BaO}^{3}$ & 0.12 & 0.07 & 0.14 & 0.15 \\
\hline $\mathrm{SO}_{3}$ & 0.03 & 0.03 & 0.02 & 0.02 \\
\hline $\mathrm{SrO}$ & 0.14 & 0.10 & 0.13 & 0.14 \\
\hline LOI_1000 & 7.57 & 1.42 & 2.55 & 2.83 \\
\hline Total & 99.58 & 99.73 & 99.46 & 99.32 \\
\hline $\mathrm{FeO}^{\mathrm{t}}$ & 6.98 & 8.81 & 9.02 & 9.16 \\
\hline Mg\# & 43.37 & 46.30 & 50.64 & 50.20 \\
\hline $\mathrm{Na}_{2} \mathrm{O}+$ & 5.48 & 5.69 & 6.68 & 6.52 \\
\hline $\begin{array}{c}\mathrm{Ka}_{2} \mathrm{O} / \mathrm{K}_{2} \mathrm{O} \\
\end{array}$ & 0.42 & 1.01 & 0.49 & 0.19 \\
\hline
\end{tabular}


Table 1. Cont.

\begin{tabular}{|c|c|c|}
\hline REE & & \\
\hline $\mathrm{Ba}$ & 1105.00 & 670.00 \\
\hline $\mathrm{Ce}$ & 122.50 & 42.80 \\
\hline $\mathrm{Cr}$ & & 10.00 \\
\hline $\mathrm{Cs}$ & 5.41 & 0.40 \\
\hline Dy & 6.09 & 4.35 \\
\hline $\mathrm{Er}$ & 2.78 & 2.20 \\
\hline $\mathrm{Eu}$ & 2.87 & 1.56 \\
\hline $\mathrm{Ga}$ & 17.10 & $\begin{array}{l}1.00 \\
20.10\end{array}$ \\
\hline $\mathrm{Gd}$ & 8.74 & 4.59 \\
\hline $\mathrm{Hf}$ & $\begin{array}{l}.0 .74 \\
5.30\end{array}$ & 2.60 \\
\hline Ho & 1.05 & 0.82 \\
\hline $\mathrm{La}$ & 64.10 & 22.30 \\
\hline $\begin{array}{l}\mathrm{La} \\
\mathrm{Lu}\end{array}$ & $\begin{array}{l}64.10 \\
0.37\end{array}$ & $\begin{array}{l}22.30 \\
0.32\end{array}$ \\
\hline $\mathrm{Nb}$ & 22.60 & 4.60 \\
\hline $\mathrm{Nd}$ & 54.90 & 24.30 \\
\hline $\mathrm{Pr}$ & 14.20 & 5.96 \\
\hline $\mathrm{Rb}$ & 124.50 & 44.40 \\
\hline Sm & 10.30 & 5.33 \\
\hline $\mathrm{Sn}$ & 1.00 & 1.00 \\
\hline $\mathrm{Sr}$ & 1320.00 & 835.00 \\
\hline $\mathrm{Ta}$ & 1.00 & 0.30 \\
\hline $\mathrm{Tb}$ & 1.17 & 0.74 \\
\hline Th & 15.10 & 4.68 \\
\hline $\mathrm{Tm}$ & 0.37 & 0.35 \\
\hline $\mathrm{U}$ & 3.44 & 1.26 \\
\hline $\mathrm{V}$ & 237.00 & 286.00 \\
\hline $\mathrm{w}$ & 1.00 & 1.00 \\
\hline Y & 30.10 & 21.90 \\
\hline $\mathrm{Yb}$ & 2.51 & 2.26 \\
\hline $\mathrm{Zr}$ & 238.00 & 83.00 \\
\hline $\mathrm{Ag}$ & 0.25 & 0.25 \\
\hline As & 7.00 & \\
\hline $\mathrm{Cd}$ & 0.25 & 0.25 \\
\hline $\mathrm{Co}$ & 19.00 & 30.00 \\
\hline $\mathrm{Cu}$ & 94.00 & 127.00 \\
\hline $\mathrm{Li}$ & 10.00 & 10.00 \\
\hline Mo & & \\
\hline $\mathrm{Ni}$ & 1.00 & 8.00 \\
\hline $\begin{array}{l}\mathrm{N1} \\
\mathrm{Pb}\end{array}$ & $\begin{array}{l}1.00 \\
15.00\end{array}$ & $\begin{array}{l}.0 .00 \\
16.00\end{array}$ \\
\hline $\mathrm{Sc}$ & 12.00 & 23.00 \\
\hline $\mathrm{Zn}$ & 85.00 & 95.00 \\
\hline Sum_REE & 291.95 & 117.88 \\
\hline $\mathrm{Dy} / \mathrm{Dy}^{*}$ & 0.65 & 0.69 \\
\hline $\mathrm{Dy} / \mathrm{Yb}$ & 2.43 & 1.92 \\
\hline $\mathrm{Eu} / \mathrm{Eu}^{*}$ & 0.93 & 0.97 \\
\hline $\mathrm{Th} / \mathrm{Hf}$ & 2.85 & 1.80 \\
\hline$(\mathrm{Ce} / \mathrm{Yb})_{\mathrm{N}}$ & 12.41 & 4.82 \\
\hline$(\mathrm{La} / \mathrm{Sm})_{\mathrm{N}}$ & $\begin{array}{l}12.41 \\
3.828\end{array}$ & $\begin{array}{l}4.02 \\
2.574\end{array}$ \\
\hline$(\mathrm{Sm} / \mathrm{Yb})_{\mathrm{N}}$ & $\begin{array}{l}\text {.020 } \\
4.45\end{array}$ & 2.56 \\
\hline Rock type & & \\
\hline Sample No. & & \\
\hline $\mathrm{SiO}_{2}$ & & \\
\hline $\mathrm{TiO}_{2}$ & & \\
\hline $\mathrm{Al}_{2} \mathrm{O}_{3}$ & & \\
\hline $\begin{array}{l}\mathrm{Al}_{2} \mathrm{O}_{3} \\
\mathrm{Fe}\end{array}$ & & \\
\hline $\mathrm{MnO}$ & & \\
\hline $\mathrm{MgO}$ & & \\
\hline $\mathrm{CaO}$ & & \\
\hline $\mathrm{Na}_{2} \mathrm{O}$ & & \\
\hline $\mathrm{K}_{2} \mathrm{O}$ & & \\
\hline $\begin{array}{l}\mathrm{K}_{2} \mathrm{O} \\
\mathrm{P}_{2} \mathrm{O}_{5}\end{array}$ & & \\
\hline $\begin{array}{l}\mathrm{C}_{2} \\
\mathrm{Cr}_{2} \mathrm{O}_{5}\end{array}$ & & \\
\hline $\mathrm{BaO}$ & & \\
\hline $\mathrm{SO}_{3}$ & & \\
\hline $\mathrm{SrO}$ & & \\
\hline LOI_1000 & & \\
\hline Total & & \\
\hline $\mathrm{FeO}^{t}$ & & \\
\hline Mg\# & & \\
\hline $\mathrm{Na}_{2} \mathrm{O}+$ & & \\
\hline $\begin{array}{c}\mathrm{Ka}_{2} \mathrm{O} / \mathrm{K}_{2} \mathrm{O}\end{array}$ & 0. & \\
\hline $\begin{array}{l}\text { Trace } \\
(\mathrm{ppm})\end{array}$ & & \\
\hline $\mathrm{Ba}$ & 132 & \\
\hline $\mathrm{Ce}$ & & \\
\hline $\mathrm{Cr}$ & & \\
\hline $\mathrm{Cs}$ & & \\
\hline Dy & 4. & \\
\hline Er & & \\
\hline $\mathrm{Eu}$ & & \\
\hline $\mathrm{Ga}$ & & \\
\hline $\mathrm{Gd}$ & & \\
\hline $\begin{array}{ll}\mathrm{Ha} \\
\mathrm{Hf}\end{array}$ & & \\
\hline $\begin{array}{l}\text { HI } \\
\text { Ho }\end{array}$ & & \\
\hline $\mathrm{La}$ & & \\
\hline $\begin{array}{l}\mathrm{La} \\
\mathrm{Lu}\end{array}$ & & \\
\hline $\mathrm{Nb}$ & & \\
\hline $\mathrm{Nd}$ & & \\
\hline $\mathrm{Pr}$ & & \\
\hline $\mathrm{Rb}$ & & \\
\hline $\mathrm{Sm}$ & & \\
\hline $\begin{array}{l}\mathrm{Sm} \\
\mathrm{Sn}\end{array}$ & 1. & \\
\hline $\mathrm{Sr}$ & 119 & \\
\hline Ta & 0. & \\
\hline $\mathrm{Tb}$ & 0. & \\
\hline Th & 9. & \\
\hline
\end{tabular}


Table 1. Cont.

\begin{tabular}{|c|c|c|c|c|c|c|c|c|c|}
\hline $\mathrm{Tm}$ & 0.31 & 0.35 & 0.33 & 0.37 & 0.26 & 0.26 & 0.22 & 0.29 & 0.30 \\
\hline $\mathrm{U}$ & 2.25 & 1.70 & 1.54 & 2.60 & 2.46 & 2.50 & 2.97 & 2.18 & 2.28 \\
\hline $\mathrm{V}$ & 298.00 & 241.00 & 271.00 & 270.00 & 318.00 & 265.00 & 207.00 & 314.00 & 320.00 \\
\hline W & 4.00 & 1.00 & 12.00 & 2.00 & 1.00 & 3.00 & 2.00 & 5.00 & 1.00 \\
\hline Y & 21.40 & 22.60 & 20.90 & 25.80 & 19.20 & $\begin{array}{l}3.00 \\
16.20\end{array}$ & 15.30 & 21.10 & 23.40 \\
\hline $\mathrm{Yb}$ & 2.01 & 2.12 & 2.02 & 2.36 & 1.72 & 1.57 & 1.35 & 1.82 & 1.91 \\
\hline $\mathrm{Zr}$ & 106.00 & 106.00 & 94.00 & 140.00 & 81.00 & $\begin{array}{l}1.37 \\
76.00\end{array}$ & $\begin{array}{l}1.03 \\
89.00\end{array}$ & $\begin{array}{l}1.02 \\
100.00\end{array}$ & $\begin{array}{l}1.91 \\
116.00\end{array}$ \\
\hline $\mathrm{Ag}$ & 0.25 & 0.25 & 0.25 & 0.25 & 0.25 & 0.25 & 0.25 & 0.25 & 0.25 \\
\hline As & 7.00 & 6.00 & & 9.00 & 14.00 & & 14.00 & 5.00 & \\
\hline $\mathrm{Cd}$ & 0.25 & 0.25 & 0.25 & 0.25 & 0.25 & 0.25 & 0.25 & 0.25 & 0.25 \\
\hline Co & $\begin{array}{l}0.20 \\
32.00\end{array}$ & 21.00 & $\begin{array}{l}0.20 \\
32.00\end{array}$ & $\begin{array}{l}0.25 \\
25.00\end{array}$ & $\begin{array}{l}0.20 \\
38.00\end{array}$ & $\begin{array}{l}0.25 \\
32.00\end{array}$ & $\begin{array}{l}0.25 \\
25.00\end{array}$ & $\begin{array}{l}0.20 \\
32.00\end{array}$ & $\begin{array}{l}0.25 \\
32.00\end{array}$ \\
\hline $\mathrm{Cu}$ & $\begin{array}{l}3.00 \\
144.00\end{array}$ & 81.00 & 98.00 & $\begin{array}{l}25.00 \\
102.00\end{array}$ & $\begin{array}{l}303.00 \\
193\end{array}$ & 181.00 & 147.00 & $\begin{array}{l}3.00 \\
137.00\end{array}$ & 130.00 \\
\hline $\mathrm{Li}$ & 20.00 & 10.00 & 10.00 & 10.00 & 20.00 & 20.00 & 20.00 & 20.00 & 10.00 \\
\hline Mo & & & 1.00 & 1.00 & & 1.00 & 1.00 & & \\
\hline $\mathrm{Ni}$ & 19.00 & 4.00 & 25.00 & 7.00 & 24.00 & 22.00 & 10.00 & 20.00 & 20.00 \\
\hline $\begin{array}{l}\mathrm{Nb} \\
\mathrm{Pb}\end{array}$ & 19.00 & $\begin{array}{l}4.00 \\
16.00\end{array}$ & 10.00 & 20.00 & 22.00 & 20.00 & 25.00 & 18.00 & 21.00 \\
\hline $\mathrm{Sc}$ & 25.00 & 15.00 & 30.00 & 20.00 & 36.00 & 28.00 & 16.00 & 30.00 & 29.00 \\
\hline $\begin{array}{l}\mathrm{sc} \\
\mathrm{Zn}\end{array}$ & $\begin{array}{l}25.00 \\
96.00\end{array}$ & $\begin{array}{l}159.00 \\
79.00\end{array}$ & $\begin{array}{l}30.00 \\
81.00\end{array}$ & 94.00 & $\begin{array}{l}36.00 \\
89.00\end{array}$ & $\begin{array}{l}28.00 \\
82.00\end{array}$ & $\begin{array}{l}10.00 \\
76.00\end{array}$ & $\begin{array}{l}30.00 \\
86.00\end{array}$ & 90.00 \\
\hline Sum_REE & 168.83 & 143.95 & 125.56 & 196.99 & 169.78 & 150.38 & 148.68 & 147.1 & 165.4 \\
\hline $\mathrm{Dy} / \mathrm{Dy}^{*}$ & 0.67 & 0.69 & 0.70 & 0.65 & 0.69 & 0.63 & $\begin{array}{l}0.61 \\
0.61\end{array}$ & 0.72 & 0.77 \\
\hline $\mathrm{Dy} / \mathrm{Yb}$ & 2.22 & 2.11 & 2.07 & $\begin{array}{l}2.03 \\
2.16\end{array}$ & $\begin{array}{l}.09 \\
2.42\end{array}$ & $\begin{array}{l}2.03 \\
2.24\end{array}$ & $\begin{array}{l}2.01 \\
2.31\end{array}$ & 2.33 & 2.56 \\
\hline $\mathrm{Eu} / \mathrm{Eu}^{*}$ & 0.81 & 0.79 & 0.86 & 0.88 & 0.86 & 0.85 & 0.86 & 0.85 & 0.86 \\
\hline Th/Hf & $\begin{array}{l}2.01 \\
2.66\end{array}$ & 2.33 & $\begin{array}{l}.00 \\
2.10\end{array}$ & $\begin{array}{l}0.00 \\
2.52\end{array}$ & $\begin{array}{l}3.00 \\
3.60\end{array}$ & 4.18 & $\begin{array}{l}5.00 \\
5.05\end{array}$ & $\begin{array}{l}2.03 \\
2.79\end{array}$ & $\begin{array}{l}0.00 \\
2.81\end{array}$ \\
\hline$(\mathrm{Ce} / \mathrm{Yb})_{\mathrm{N}}$ & 8.28 & 6.61 & 5.93 & 8.49 & 9.80 & 9.64 & 11.44 & 8.02 & 8.64 \\
\hline$(\mathrm{La} / \mathrm{Sm})_{\mathrm{N}}$ & $\begin{array}{l}0.2004 \\
2.904\end{array}$ & $\begin{array}{l}2.054 \\
2.954\end{array}$ & 2.69 & 3.406 & 2.947 & 3.617 & 4.26 & $\begin{array}{l}0.02 \\
3.065\end{array}$ & $\begin{array}{l}0.04 \\
3.022\end{array}$ \\
\hline$(\mathrm{Sm} / \mathrm{Yb})_{\mathrm{N}}$ & 4.05 & 3.09 & 2.99 & 3.47 & 4.80 & 4.00 & 4.15 & 3.55 & 3.88 \\
\hline
\end{tabular}

\subsubsection{The Tephritic Dykes}

The tephritic dykes are porphyritic rocks with a microcrystalline or hypocrystalline groundmass. The tephritic dykes are mainly massive, and their color varies from black to greyish-green categories based on alterations. Microscopically, the tephritic dykes are composed of plagioclase of a labradorite composition, with analcime, pyroxene and amphibole as the principal constituents (Figure $4 a, b)$. Sometimes, minor amounts of chlorite and epidote are secondary minerals. Plagioclase is present as either tabular and prismatic phenocrysts (up to $3.5-2.5 \mathrm{~mm}$ ) or fine-grained laths (up to $0.4 \mathrm{~mm}$ across) in the groundmass. Euhedral to subhedral tabular plagioclase phenocrysts display lamellar twinning and zoning. In some places, plagioclase crystals are slightly altered to sericite, especially in the cores (Figure 4a). Pyroxene is in the form of euhedral to subhedral prismatic phenocrysts and granular aggregates in the groundmass. It is colorless to pale-brown, and occasionally shows simple twinning (Figure $4 \mathrm{~b}$ ). The poikilitic crystals contain inclusions of plagioclase, apatite, zircon and opaque minerals. The euhedral to subhedral analcime phenocrysts are $20-30 \%$ in volume (Figure 4a), and these minerals have a black and dark-grey color in their core (Figure 4a). The analyzed analcimes are almost homogenous in chemical composition. Petrography, mineral chemistry and SEM studies revealed that all analcimes in the studied shoshonitic succession were produced through the Na-metasomatism of leucite crystals.

\subsubsection{The Andesitic Dykes}

The andesite dykes are of limited abundance among the intermediate dyke swarms. Macroscopically, they are fine-grained, massive with a dark-grey to green color and range from aphyric to typical porphyritic varieties. The andesite dykes are composed of plagioclase, pyroxene and amphibole as essential minerals (Figure 4c-e). Chlorite, actinolite, epidote and sericite are alteration products. Accessory minerals are apatite, titanite, olivine and zircon. Plagioclase $\left(\mathrm{An}_{25}-\mathrm{An}_{40}\right)$, partially altered to sericite and epidote, is the most abundant mineral component, occurring as euhedral to subhedral phenocrysts of prismatic habit (up to $2 \mathrm{~mm}$ ), while laths (up to $0.2 \mathrm{~mm}$ long) form the majority of the groundmass (Figure 4e). In some instances, the plagioclase phenocrysts are twinned and zoned. Apatite and zircon occur mainly as inclusions in Cpx crystals (Figure 4d). Pyroxene is in the form of euhedral to subhedral prismatic phenocrysts and granular aggregates in the groundmass (Figure 4c,d). 

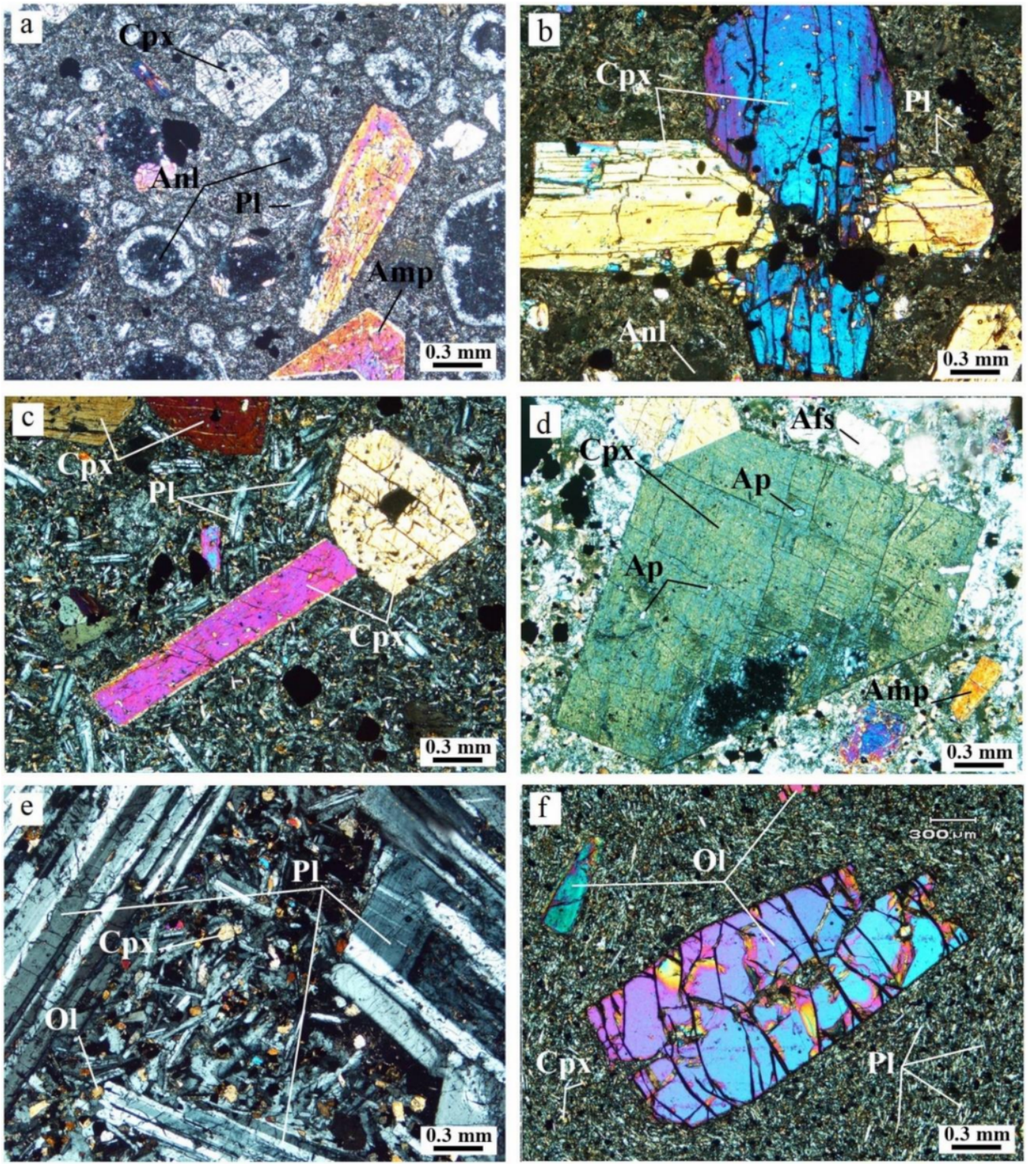

Figure 4. Photomicrographs in crossed polarized light of dyke rocks. (a) Analcime, plagioclase and amphibole in tephrite. (b) Sector-zoned clinopyroxene, plagioclase and analcime in tephrite. (c) Clinopyroxene and plagioclase phenocrysts in pyroxene andesite with porphyric texture. (d) Euhedral clinopyroxene with apatite inclusions and subhedral amphiboles in pyroxene andesites. (e) Plagioclase phenocrysts, clinopyroxene and olivine with seriate texture in andesite basalt. (f) Olivine phenocrysts and plagioclase in olivine basalt. Mineral abbreviations from [57]: $\mathrm{Amp}=$ amphibole, $\mathrm{Pl}=$ plagioclase, $\mathrm{Cpx}=$ clinopyroxene, $\mathrm{Anl}=$ analcime, $\mathrm{AP}=$ apatite, $\mathrm{Afs}=$ alkali feldspar and $\mathrm{Ol}=$ Olivine.

\subsubsection{The Basaltic and Basaltic-Andesitic Dykes}

The basaltic dykes are the most common rock varieties among the mafic dyke swarm. Macroscopically, these dyke rocks are mainly massive, and the color varies from black to grayish green according to the extent of alteration. Microscopically, the basalt and basalticandesite dykes are composed of plagioclase of a labradorite composition $\left(\mathrm{An}_{55-60}\right)$, with pyroxene and olivine as principal constituents. Sometimes, minor amounts of chlorite and epidote are present as secondary minerals, while opaque minerals, apatite and zircon are the main accessories. Plagioclase is present as either tabular and prismatic phenocrysts (up to $3.5-2.5 \mathrm{~mm}$ ) or fine-grained laths (up to $0.4 \mathrm{~mm}$ across) in the groundmass. The pyroxene 
is mainly diopside to augite in the form of euhedral to subhedral prismatic phenocrysts and granular aggregates in the groundmass. It is colorless to pale-brown and occasionally shows sector zoning. Olivine crystals present as euhedral to subhedral phenocrysts (up to 2-3 $\mathrm{mm}$ ) and are fine-grained in groundmass (Figure $4 \mathrm{f}$ ).

\subsection{Geochemistry}

\subsubsection{Major Elements}

The studied samples have slight alterations, characterized by a low content of LOI (1.1-3.9 wt.\%), while the tephritic rocks have a high LOI that results from the presence of analcime in these rocks (Table 1). The $\mathrm{SiO}_{2}$ content, ranging from 44.8 to $59.6 \mathrm{wt} . \%$, and $\mathrm{MgO}$, from 0.55 to $7.96 \mathrm{wt} . \%$, with $\mathrm{Mg} \#=(100 \times \mathrm{MgO} /(\mathrm{MgO}+\mathrm{FeOt}))$ of $23.80-60.25$ (Table 1). The $\mathrm{K}_{2} \mathrm{O} / \mathrm{Na}_{2} \mathrm{O}$ ratios vary in the range of 0.86-5.27 and their $\mathrm{K}_{2} \mathrm{O}$ content is in the range of 2.59-7.36. In addition, they are all characterized by high concentrations of $\mathrm{Na}_{2} \mathrm{O}+$ $\mathrm{K}_{2} \mathrm{O}\left(4.58-12.5\right.$ wt.\%), $\mathrm{Al}_{2} \mathrm{O}_{3}(11.45-21.60 \mathrm{wt} . \%)$ and $\mathrm{TiO}_{2}(0.39-1.41 \mathrm{wt} . \%)$ (Table 1). In the IUGS classification (TAS diagram) total alkali versus silica plot [58], samples are mainly plot in the intersection field of basaltic-andesite, andesite, trachy basalt, basaltic trachy andesite and alkali basalt compositions (Figure 5). Using different diagrams, such as $\mathrm{SiO}_{2}$ versus $\mathrm{K}_{2} \mathrm{O}$ [6], Co versus $\mathrm{Th}$ [59], $\mathrm{Ta} / \mathrm{Yb}$ versus $\mathrm{Ce} / \mathrm{Yb}$ and $\mathrm{Ta} / \mathrm{Yb}$ versus $\mathrm{Th} / \mathrm{Yb}$ diagrams for dykes [60], suggested that the dykes show affinity to shoshonitic rocks (Figure 6a-c).

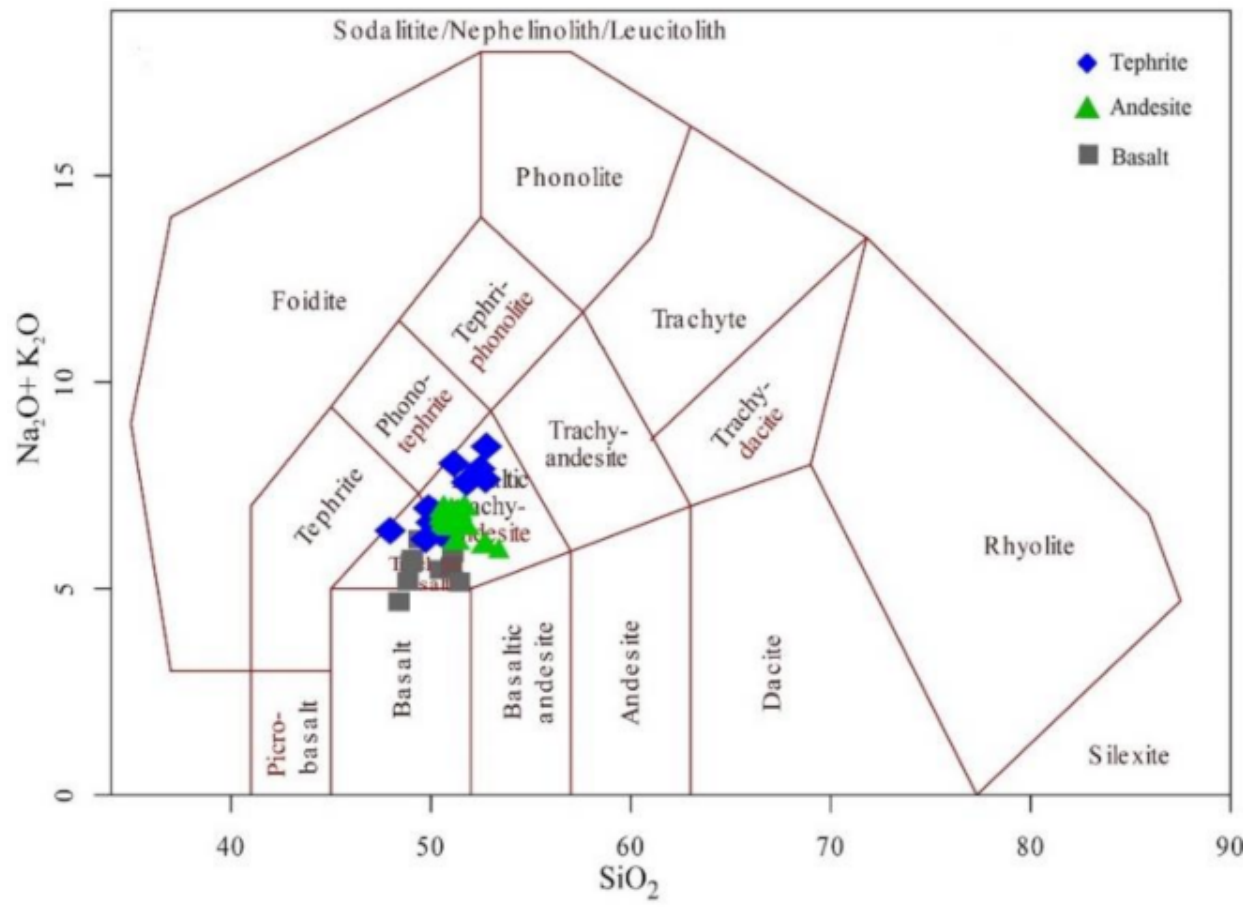

Figure 5. Total alkali versus silica (TAS) classification diagram [58].

\subsubsection{Trace Elements}

The geochemical variation diagram for $\mathrm{Cr}$ and some large-ion lithophile elements (LILEs) against $\mathrm{MgO}$ show that $\mathrm{Ni}, \mathrm{Sc}, \mathrm{V}, \mathrm{Co}$ and $\mathrm{Cr}$ increase and $\mathrm{Eu}, \mathrm{Zr}, \mathrm{Tb}, \mathrm{Ce}, \mathrm{La}, \mathrm{Sm}$ and $\mathrm{Nd}$ decrease (Figure 7). A strong, positive correlation between $\mathrm{MgO}$ and $\mathrm{Ni}, \mathrm{Cr}, \mathrm{Co}$, $\mathrm{V}$ and $\mathrm{Sc}$, suggests olivine and pyroxene fractionation. These samples are enriched in large-ion lithophile elements (LILE, such as $\mathrm{K}, \mathrm{Rb}, \mathrm{Sr}$ and $\mathrm{Ba}$ ) and have a wide range of concentrations of $\mathrm{Cr}$ and $\mathrm{Ni}$ (Figure 7). They also show negative Eu anomalies with $\left(\mathrm{Eu} / \mathrm{Eu}^{*}\right)$ ratios ranging from 0.80 to 0.97 for basalts, 0.72 to 0.91 for the andesites and 0.78 to 0.87 for the tephrites (Table 1). Primitive mantle-normalized, trace element spider diagrams for dykes are presented in Figure 8a,b, and all the samples are mainly characterized by strong enrichment in LILEs (e.g., $\mathrm{Rb}, \mathrm{Ba}, \mathrm{U}, \mathrm{K}$ and Th). They are also characterized by 
conspicuous negative anomalies of HFSEs, including $\mathrm{Nb}$, $\mathrm{Ta}$ and $\mathrm{Ti}$, relative to LREEs (Figure 8a). The depletion in $\mathrm{Nb}-\mathrm{Ta}$ is commonly considered to be a typical feature of subduction-related magmatism. The enrichment in LILEs and depletion in HFSEs are considered to be main features of subduction zone-related magmas [60-62]. In contrast to major elements, REEs are more dependent on the mineralogy of the mantle source and, hence, reflect the process of melt formation and extraction [63]. Although various modal mineralogy and relatively different signatures of major and some trace elements characterize the lavas, they display similar chondrite-normalized REE patterns (Figure 8b). The rocks are strongly enriched in light REE (90-374 times chondrite for La) relative to HREE (6-15 times chondrite for $\mathrm{Yb}$; Figure $8 \mathrm{~b}$ ). The $\mathrm{La}(\mathrm{n}) / \mathrm{Yb}(\mathrm{n})$ ratios vary between 13 and 40 and the $(\mathrm{Ce} / \mathrm{Yb}) \mathrm{N}$ ratio between 4.48 and 12.41 for the dyke samples. A high LREE/HREE ratio in the high-K rocks could be related to the low degree of partial melting of an enriched mantle source. REE enrichment can be controlled by many things, and the melting of garnet and phlogopite is only one aspect of them [64]. The dykes have high abundances (300 times primitive mantle) of LIL elements, such as $\mathrm{Sr}, \mathrm{Rb}, \mathrm{Ba}, \mathrm{Th}, \mathrm{U}, \mathrm{La}$, and Ce, but near-basaltic values (10 times primitive mantle) for the HFSEs, Dy, Y, Er, Yb, and Lu. They display a relative depletion of Th (10 ppm), U (1.7 ppm) and Hf (4.9 ppm) (Figure 8b).
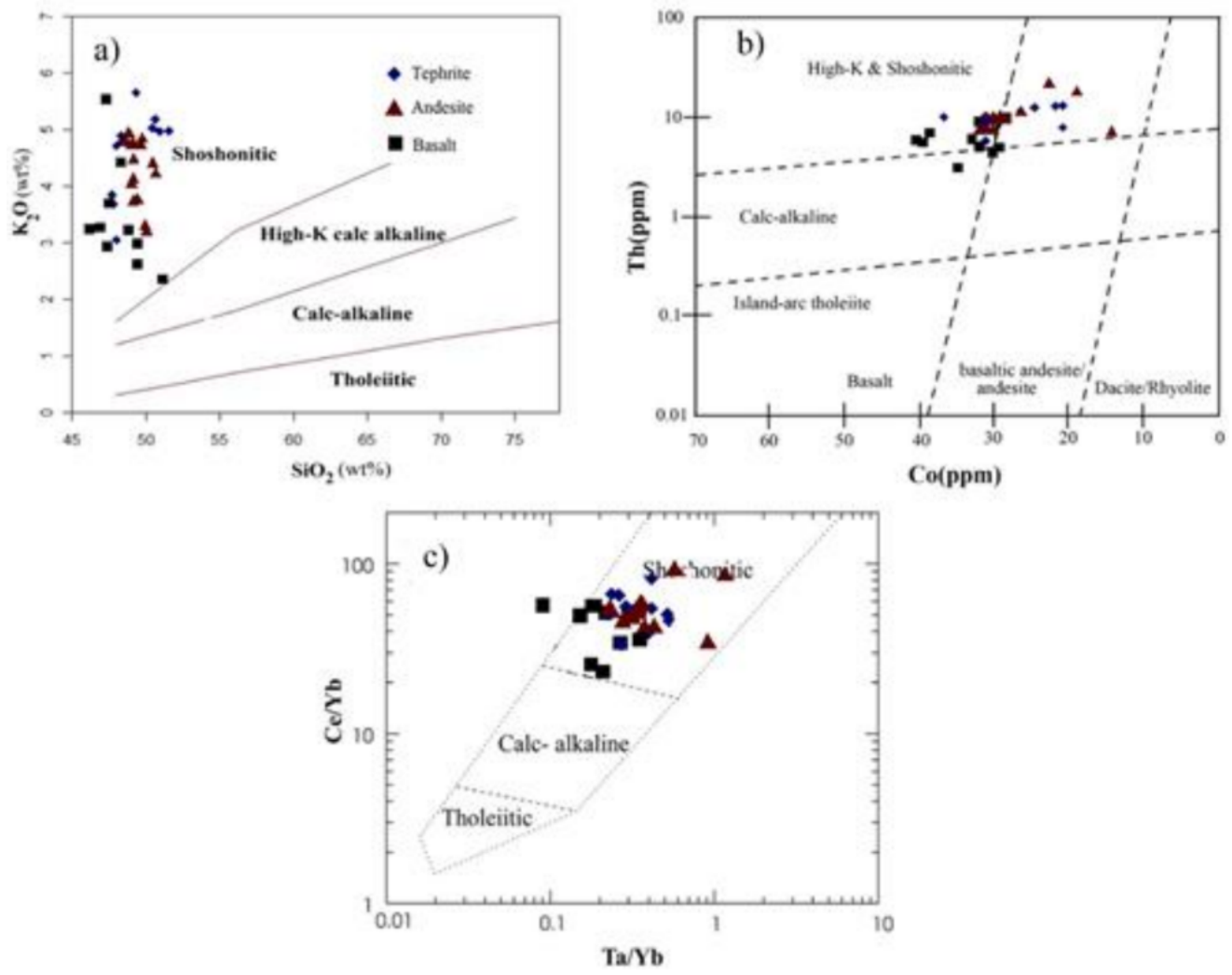

Figure 6. (a) $\mathrm{SiO}_{2}$ versus $\mathrm{K}_{2} \mathrm{O}$ [6]. (b) Co versus $\mathrm{Th}$ [59]. (c) $\mathrm{Ta} / \mathrm{Yb}$ versus $\mathrm{Ce} / \mathrm{Yb}$ and [60].

\subsubsection{Sr-Nd Isotope Geochemistry}

The Nd-Sr isotopic ratios of the dyke swarm rocks are given in Table 2. The initial $(43 \mathrm{Ma}){ }^{87} \mathrm{Sr} /{ }^{86} \mathrm{Sr}$ ratio of these rocks varies between 0.70503 and 0.70534 , and it has variable $\varepsilon \mathrm{Nd}(\mathrm{t})$ values $(1.96$ to -1.46$)$. Their initial ${ }^{143} \mathrm{Nd} /{ }^{144} \mathrm{Nd}$ ratio shows a narrow range between 0.51255 and 0.51273 . The ${ }^{147} \mathrm{Sm} /{ }^{144} \mathrm{Nd}$ versus ${ }^{143} \mathrm{Nd} /{ }^{144} \mathrm{Nd}$ diagram, on which all nine data points for the dyke swarm rocks in Table 2 have been plotted, and all the samples plotted in the mantle array field display a tendency to enrich the mantle source (Figure 9). 

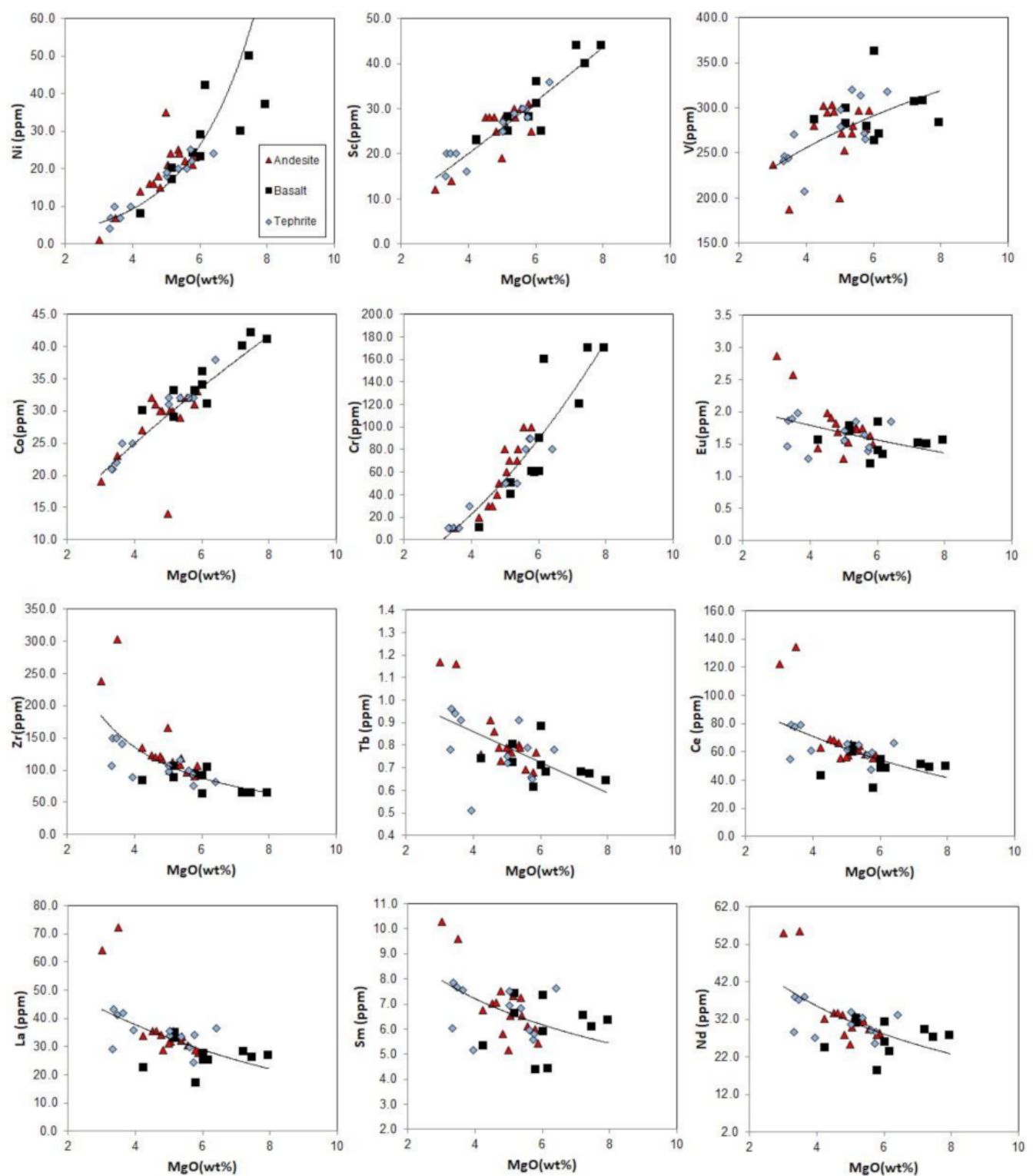

Figure 7. Geochemical variation diagram for $\mathrm{Ni}, \mathrm{Sc}, \mathrm{V}, \mathrm{Co}, \mathrm{Cr}, \mathrm{Eu}, \mathrm{Zr}, \mathrm{Tb}, \mathrm{Ce}, \mathrm{La}, \mathrm{Sm}$ and $\mathrm{Nd}$ elements against $\mathrm{MgO}$.
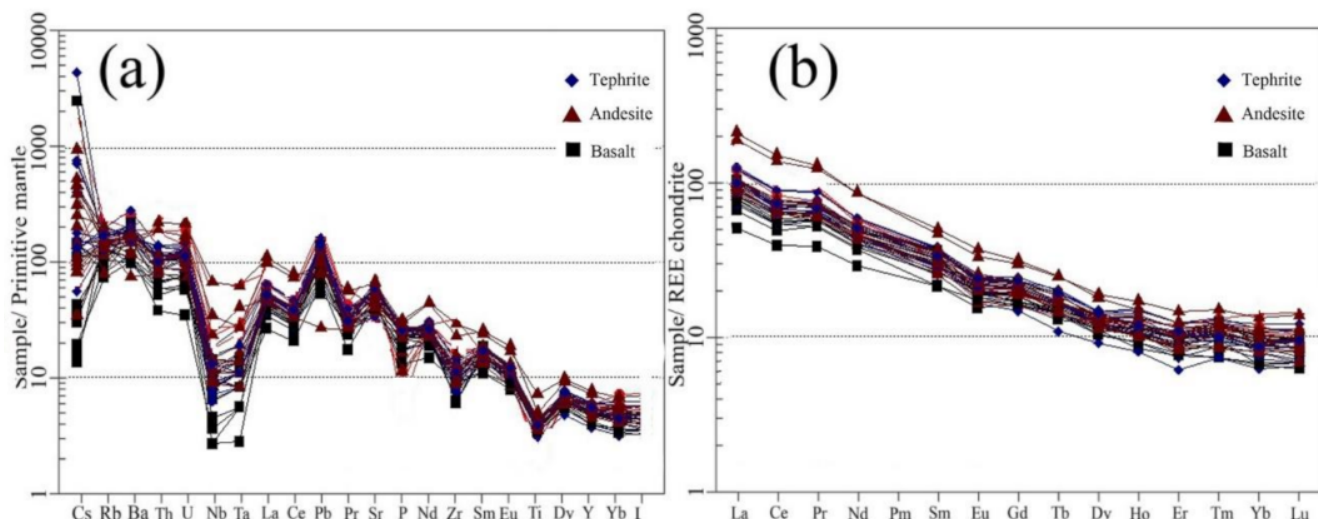

Figure 8. $(\mathbf{a}, \mathbf{b})$ Primitive mantle-normalized multi-element spider diagrams for the studied mafic dyke samples. Primitive mantle and REE chondrite values are taken from [65]. 
Table 2. Initial ratios for $87 \mathrm{Sr} / 86 \mathrm{Sr}$ and $143 \mathrm{Nd} / 144 \mathrm{Nd}$ of the dyke swarms.

\begin{tabular}{|c|c|c|c|c|c|c|c|c|c|c|c|c|}
\hline $\begin{array}{c}\text { Sample } \\
\text { No. }\end{array}$ & $\begin{array}{l}\text { Rock } \\
\text { Type }\end{array}$ & $\mathbf{R b}(\mathrm{ppm})$ & Sr (ppm) & ${ }^{87} \mathrm{Rb} /{ }^{86} \mathrm{Sr}$ & ${ }^{87} \mathrm{Sr} /{ }^{86} \mathrm{Sr}$ & Error (2 s) & Sm (ppm) & Nd (ppm) & ${ }^{147} \mathrm{Sm} /{ }^{144} \mathrm{Nd}$ & ${ }^{143} \mathrm{Nd} /{ }^{144} \mathrm{Nd}$ & Error (2s) & $\varepsilon \mathbf{N d}$ \\
\hline Dy-22B & Basalt & 56.48 & 1029 & 0.1589 & 0.705144 & 0.000010 & 6.356 & 30.17 & 0.1275 & 0.512628 & 0.000015 & 0.03 \\
\hline Dy-24 & Tephrite & 62.59 & 1170 & 0.1547 & 0.705250 & 0.000010 & 6.653 & 31.18 & 0.1292 & 0.512660 & 0.000012 & 0.64 \\
\hline Dy- 47 & Tephrite & 125.7 & 1165 & 0.3122 & 0.705234 & 0.000010 & 7.859 & 36.95 & 0.1288 & 0.512553 & 0.000015 & -1.46 \\
\hline Dy-59A & Tephrite & 124.9 & 1179 & 0.3066 & 0.705295 & 0.000013 & 4.948 & 24.76 & 0.1210 & 0.512709 & 0.000014 & 1.62 \\
\hline Dy-63B & Basalt & 18.23 & 326.8 & 0.1614 & 0.705212 & 0.000009 & $\begin{array}{l}4.730 \\
4.730\end{array}$ & 16.63 & 0.1722 & 0.512728 & 0.000014 & $\begin{array}{l}1.02 \\
1.84\end{array}$ \\
\hline $\begin{array}{l}\text { Dy-71 } \\
\text { D }\end{array}$ & Basalt & 64.48 & 743.4 & 0.2510 & 0.705250 & 0.000012 & 4.922 & 23.41 & 0.1273 & 0.512636 & 0.000012 & 0.17 \\
\hline Dy-78 & Andesite & 70.48 & 965.1 & 0.2113 & 0.705339 & 0.000012 & 6.549 & 31.06 & 0.1276 & 0.512570 & 0.000015 & -1.11 \\
\hline Dy-81 & Tephrite & 75.84 & 804.8 & 0.2727 & 0.705255 & 0.000012 & 6.210 & 28.68 & 0.1311 & 0.512660 & 0.000012 & 0.63 \\
\hline Dy-88 & Andesite & 96.19 & 770.9 & 0.3611 & 0.705030 & 0.000012 & 9.92 & 54.46 & 0.1103 & 0.512725 & 0.000012 & 1.96 \\
\hline
\end{tabular}

$\mathrm{T}_{\mathrm{DM}}(\mathrm{Ma})$-two-stage depleted mantle $\mathrm{Nd}$ model ages [66] calculated using present-day depleted mantle values of ${ }^{143} \mathrm{Nd} /{ }^{144} \mathrm{Nd}=0.51315$ and ${ }^{147} \mathrm{Sm} /{ }^{144} \mathrm{Nd}=0.2136$. CHUR values: ${ }^{87} \mathrm{Rb} /{ }^{86} \mathrm{Sr}=0.0847,{ }^{87} \mathrm{Sr} /{ }^{86} \mathrm{Sr}=0.7047$ ${ }^{147} \mathrm{Sm} /{ }^{144} \mathrm{Nd}=0.1967$ and ${ }^{143} \mathrm{Nd} /{ }^{144} \mathrm{Nd}=0.51263$.

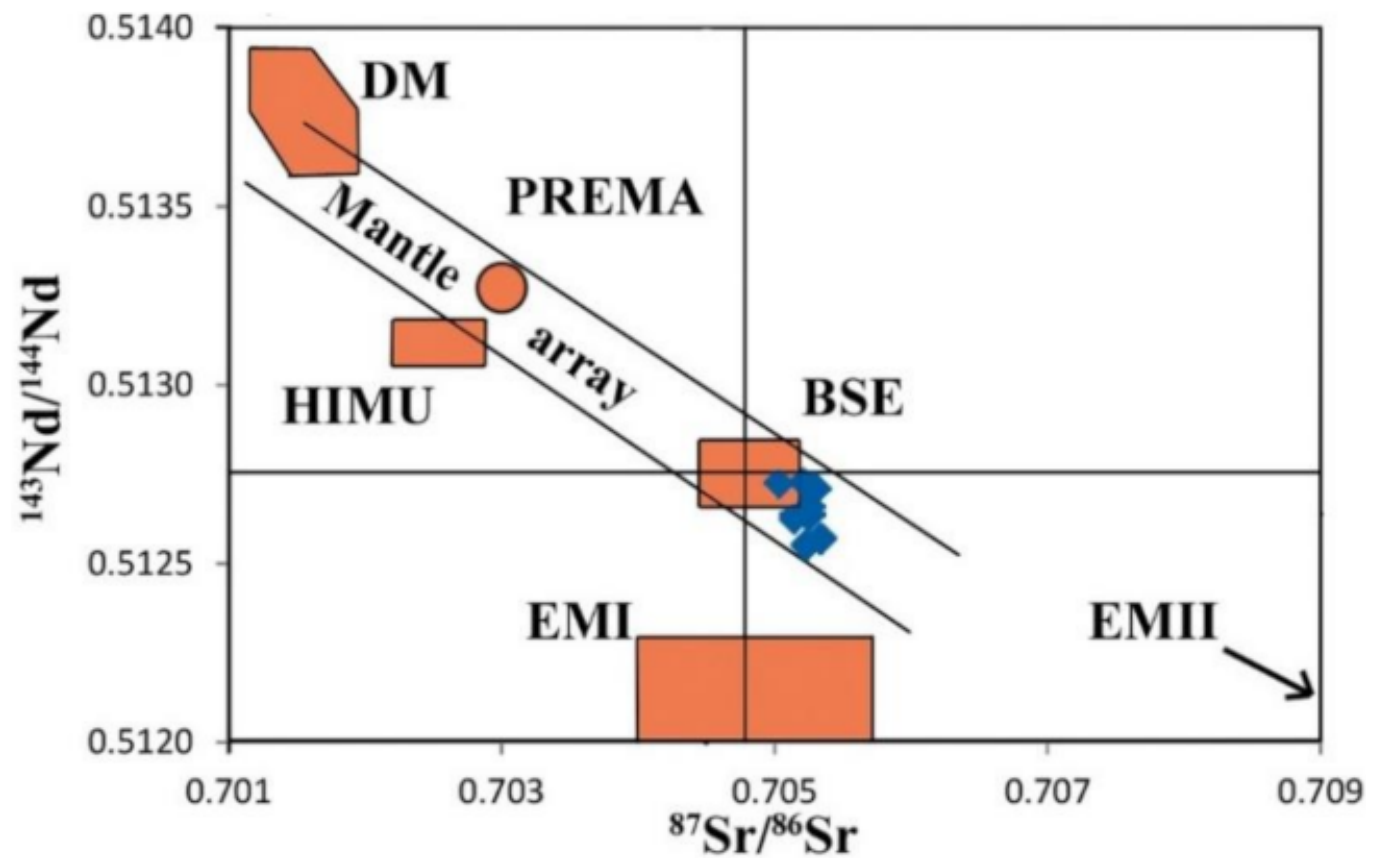

Figure 9. ${ }^{87} \mathrm{Rb} /{ }^{86} \mathrm{Sr}$ versus ${ }^{87} \mathrm{Sr} /{ }^{86} \mathrm{Sr}$ diagram for the dyke swarm rocks. All 9 samples were used in the isochron and age calculations. The bars represent the two-sigma uncertainties. ${ }^{143} \mathrm{Nd} /{ }^{144} \mathrm{Nd}$ versus ${ }^{87} \mathrm{Sr} /{ }^{86} \mathrm{Sr}$ ratio for dyke swarms with the mantle components HIMU, EM1, EM2 and DMM [63]. The positions of the main oceanic mantle reservoirs thus identified are shown: DM= depleted mantle, $\mathrm{BSE}=$ bulk silicate earth, $\mathrm{EMI}$ and EMII = enriched mantle I and II, HIMU = high mantle U/Pb ratio and PREMA = frequently observed prevalent mantle composition. Many oceanic basalts define the mantle array, and a bulk earth value for ${ }^{87} \mathrm{Sr} /{ }^{86} \mathrm{Sr}$ can be obtained from this trend.

\subsubsection{Zircon U-Pb Isotopic Dating}

Zircons from these rocks show complex morphologies and a variety of internal structures, as revealed by CL images (Figure 10). The analyzed zircons are euhedral and show prismatic forms. They are relatively small, with an average length of the long axis being $\sim 50-200 \mu \mathrm{m}$, and the length-to-width ratios about 2:1. All zircons are transparent and colorless, and they show oscillatory zoning indicative of magmatic growth. Therefore, the ages obtained from the $\mathrm{U}-\mathrm{Pb}$ isotopic data are interpreted as representing the timing of crystallization of the dated zircons and, thus, the timing of the emplacement of the rocks. The $\mathrm{U}-\mathrm{Pb}$ age results are plotted in Concordia diagrams in Figure 11. Twenty-two spots on zircon subhedral based on grain morphology were measured, and the analytical results are presented in Table 3. These zircons have moderate U (146-3228 ppm) and Th (108-1889 ppm) contents, and Th/U ratios between 0.39 and 1.28 . Twenty-two analyses were conducted with 21 zircons, which yield a mean age at $44.3 \pm 1.8 \mathrm{Ma}$, indicating that they conform to the Eocene period (Lutetian stage) (Figure 11), which we interpret as the time of crystallization of the swarm dyke's magmas. 


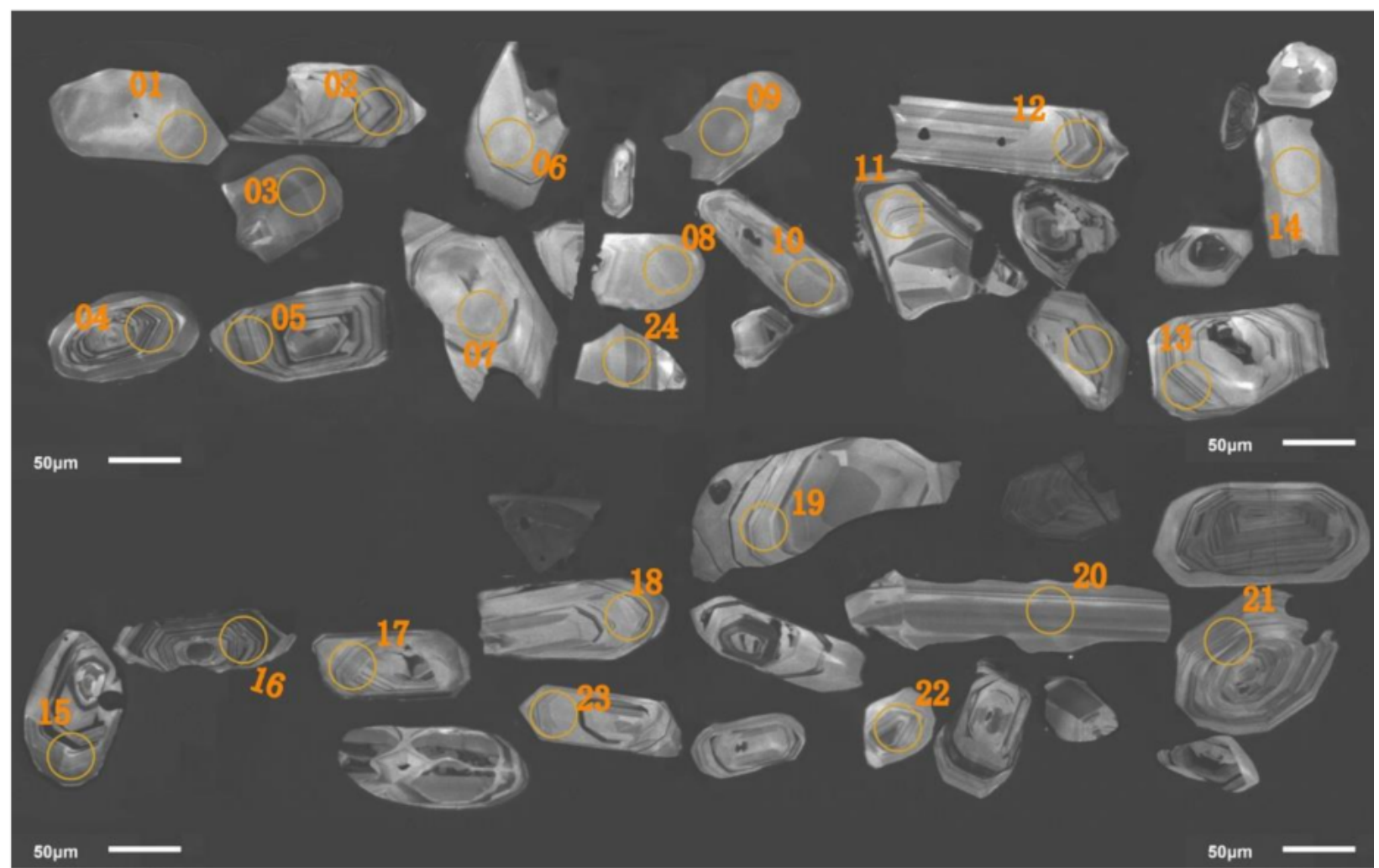

Figure 10. Cathodoluminescence (CL) images of zircons from samples of LA-ICP-MS U-Pb analyses.

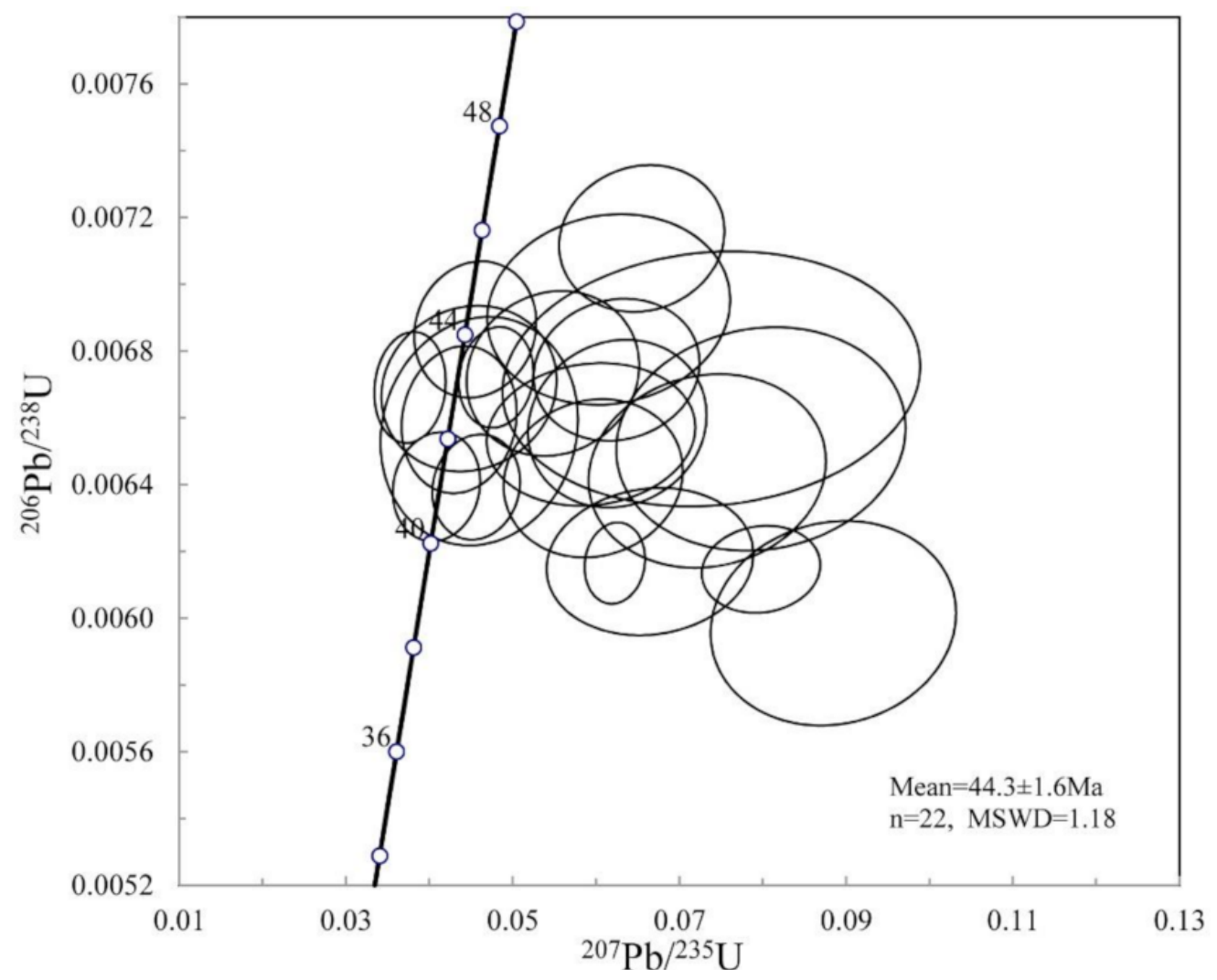

Figure 11. LA-ICP-MS zircon U-Pb Concordia diagrams for the investigated dykes from the NW of Iran. 
Table 3. LA-ICP-MS zircon U-Pb dating data of the dyke swarms.

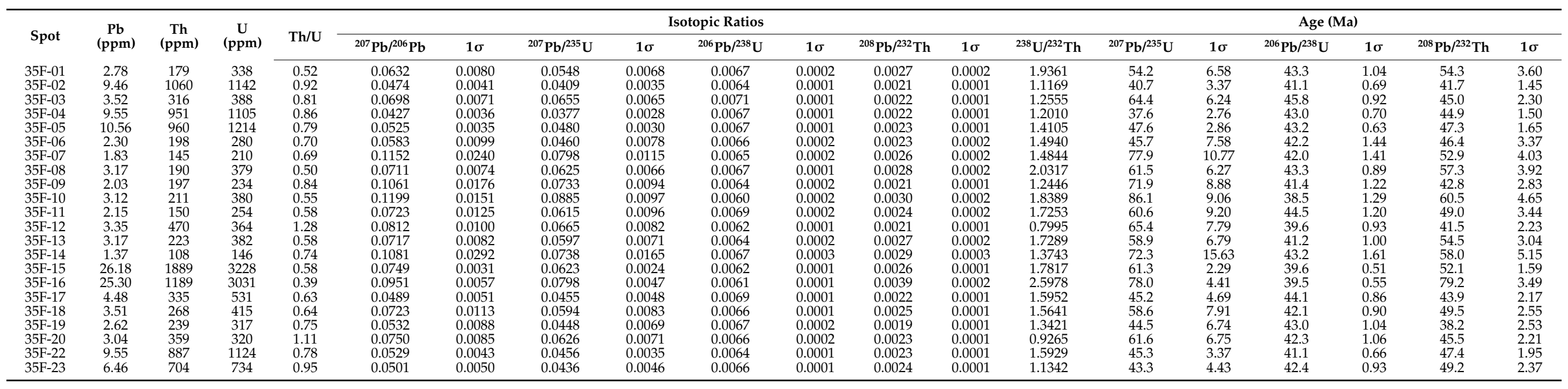




\section{Discussion}

\subsection{Partial Melting}

Potassium-rich magmatic rocks occur widely in different tectono-magmatic environments, such as in continental active margins and in post-collision and within plate settings [67-71]. It is widely accepted that the Late Cenozoic magmatism in the MediterraneanIran regions occurred in a post-collisional setting and resulted from the partial melting of a subduction-related metasomatized sub-continental lithospheric mantle [37,72-80]. Most of the high-K rocks from the Anatolian plateau are thought to have been derived from the partial melting of a mantle source, either contaminated by multi-stages of oceanic subduction events during a long period and/or contaminated by continental subduction [77,81,82]. The whole-rock composition of studied samples indicates that the $\mathrm{SiO}_{2}$ content of samples varies from 46 to $51.3 \%$ and the $\mathrm{Mg} \#$ range is about 43 to 60 , which is suggestive of a mantlederived source. Furthermore, the dyke swarms of northeast of Meshkinshahr are enriched in LILEs and LREEs relative to the primary mantle and indicate quite a flat HREE pattern (Figure 9). The lack of garnet in the mantle source indicates partial melting of the shallow upper mantle at less than $\sim 75 \mathrm{~km}$ [83]. In comparison with typical mid-ocean ridge basalts, the samples have much higher HFSE/HREE and LREE/HREE ratios (e.g., Figure 8a). This finding indicates that either the mantle source of the studied samples was significantly more enriched in incompatible elements than DMM, or that the degree of partial melting beneath the $45 \mathrm{~km}$-thick Iranian microplate crust was considerably lower than the $~ 5-15 \%$ expected for typical MORB-source mantle [84]. Both conclusions are likely to be valid, as low-degree melting will preferentially sample more fertile and, thus, more incompatible element-enriched sources. The incompatible element-enriched signature of the studied samples relative to MORB and mantle array is obvious on a Th/Yb vs. Ta/Yb plot (Figure 13). Samples also have high $\mathrm{Th} / \mathrm{Yb}$ ratios, which are taken to reflect, in the absence of evidence for widespread crustal contamination, the presence of a subduction-modified mantle source. Additional evidence for a subduction-modified source comes from the negative $\mathrm{Nb}-\mathrm{Ta}$ anomalies on the normalized plots (Figure 6a), reflecting the preservation of these HFSEs in insoluble components, such as rutile in the subducting slab (e.g., $[85,86])$. Furthermore, $\mathrm{Sr}$ and $\mathrm{Nd}$ radiogenic isotopic data preclude the depleted mantle source and the possibility of extensive contamination crustal for the genesis of Meshkinshahr dike swarm samples. The plot of Dy/Dy* vs. Dy/Yb with extended Dy/Yb (Figure 12a) shows that the dyke swarms northeast of Meshkinshahr are enriched in LILEs and LREEs relative to the primary mantle and mark the presence of crustal components. In Figure 12b, we modeled REE abundances and ratios (samples with $\mathrm{SiO}_{2}<54 \%$ ) to constrain the source characteristics of the dyke swarm magma(s) in terms of REE concentrations, source mineralogy and degree of partial melting. The modeling uses the non-modal batch melting equations of [87] and the REE partition coefficient compilation of $[88,89]$. We used two different reference compositions to define the likely mantle array: (1) the depleted MORB mantle (DMM), which is assumed here to represent the conversion of the asthenospheric mantle to the composition of the hypothetical depleted MORB source proposed by [88]; and (2) the primitive mantle (PM from [90]), which is representative of the initial mantle composition prior to MORB formation and depletion. The results of modeling are first examined in terms of the concentrations of the highly incompatible element La and less incompatible element Sm. Neither La nor $\mathrm{Sm}$ is affected significantly by variations in the source mineralogy (e.g., garnet or spinel) and, thus, they can provide information on the bulk chemical composition of the source. Figure $12 \mathrm{~b}$ shows that variable degrees of partial melting of a spinel lherzolite source cannot explain the composition of the studied rocks, as these plots are well above the mantle array and spinel lherzolite melting trends. However, the plotted samples are also below the garnet lherzolite melting trend, even for an enriched mantle composition. In order for garnet lherzolite to be a viable source for mineralogy, the partition coefficients used would have to be significantly erroneous (for $\mathrm{Yb}$ in particular), yet these values are well established. The simplest model to account for the REE systematics of the dyke samples, thus, involves garnet + spinel mantle mineralogy. The melt modeling presented above shows 
that the source of rocks is enriched in LREE relative to DMM (and PM). These features suggest that the dyke swarm were derived from small degrees of the partial melting of subduction-metasomatized (subcontinental) lithospheric mantle source. However, the mixing of melts from the two types of mantle source is suggested based on trace elements ratios (Figure 12a,b). This scenario is very consistent with those of the other post-collisional magmatic rocks from the Turkish-Iranian high plateau [25,35,91-94]. Slab break-off and/or partial delamination (due to the roll-back of the subducting Tethyan lithosphere) of the mantle lithosphere associated with the partial melting of clinopyroxene-amphibole-garnet (and/or phlogopite)-rich metasomatic veins in the lithospheric mantle in a post-collisional setting have been suggested as likely processes [25]. In this model, the first batches of lava were derived mainly from the metasomatic veins and are mostly ultrapotassic as compared to the later high-K calc-alkaline and/or shoshonitic products, which were suggested to have resulted from the melting of veins surrounding peridotites $[95,96]$. Continental collision led to slab break-off and the development of an asthenospheric window, facilitating the partial melting of the subduction-contaminated sub-continental lithospheric mantle and generating the high-K rocks as well as adakites in the region $[25,97]$.
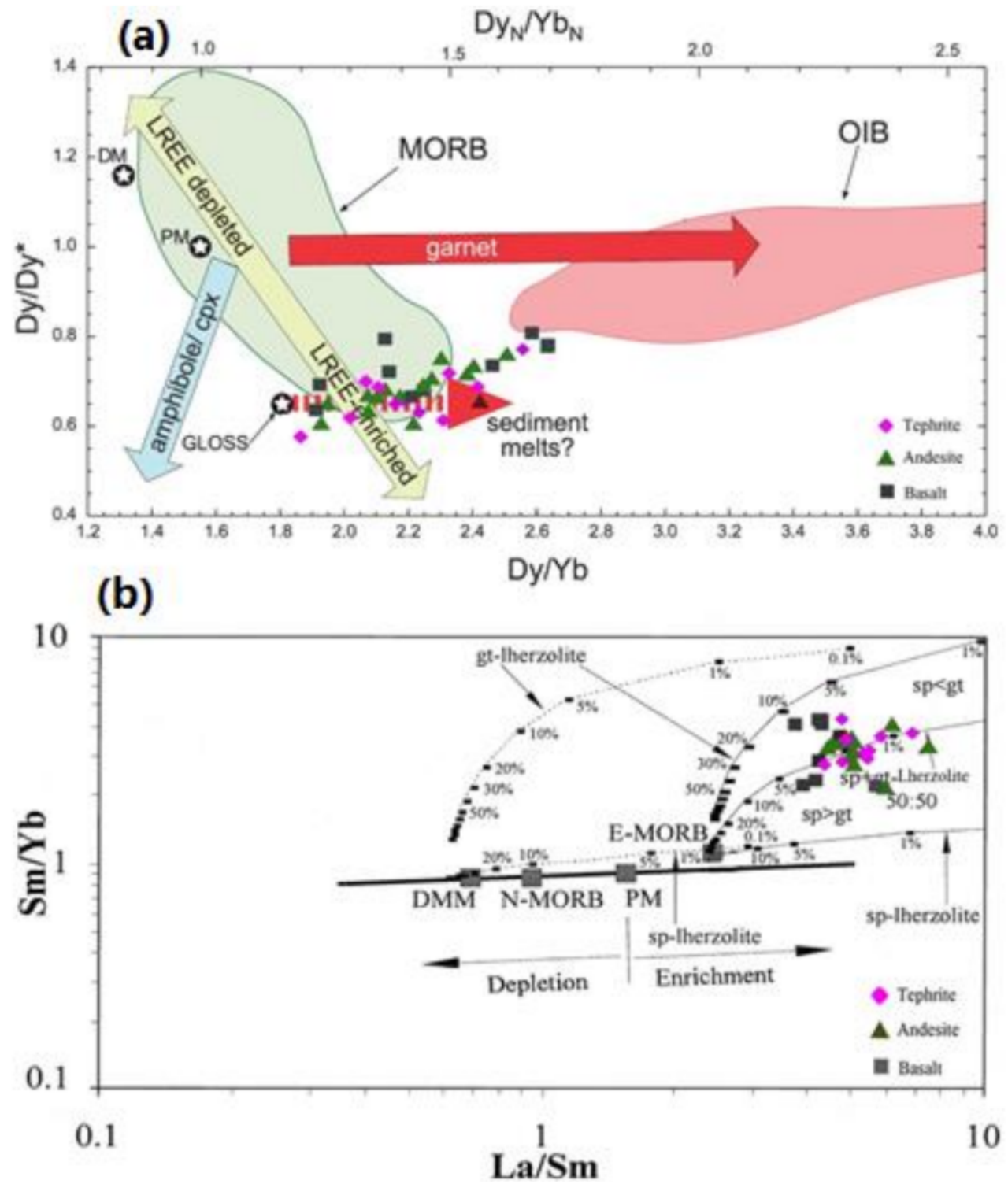

Figure 12. (a) Plot of Dy/Dy* vs. Dy/Yb with extended $\mathrm{Dy} / \mathrm{Yb}$ scale to show fields for MORB and OIB of [98]. The OIB field extends to a much higher $\mathrm{Dy} / \mathrm{Yb}$ (Samoa Dy/Yb as high as 12), reflecting 
the role of residual garnet. The OIB field includes data from Hawaii $[99,100]$ and the Azores [101]. The MORB field includes N-MORB and E-MORB data from the East Pacific Rise [102-104]. PM, primitive mantle [90]; DM, depleted mantle [105]; GLOSS, average global subducting sediment [106]. In this diagram, the study samples are plotted in the LREE-enriched mantle field. (b) Plot of La/Sm vs. $\mathrm{Sm} / \mathrm{Yb}$, showing melt curves (or lines) obtained using the non-modal batch melting equations of [87]. Melt curves are drawn for spinel lherzolite (with mode and melt mode of $\mathrm{Ol}_{0.530}+\mathrm{opx}_{0 \cdot 270}+\mathrm{cpx}_{0 \cdot 170}$ $+\mathrm{sp}_{0.030}$ and $\mathrm{ol}_{0.060}+\mathrm{opx}_{0.280}+\mathrm{cpx}_{0.670}+\mathrm{sp}_{0.110}$, respectively [107]) and for garnet lherzolite (with mode and melt mode of $\mathrm{ol}_{0} \cdot 600+\mathrm{opx}_{0} \cdot 200+\mathrm{cpx}_{0} \cdot 100+\mathrm{gt}_{0} \cdot 100$ and $\mathrm{ol}_{0} \cdot 030+\mathrm{opx}_{0 \cdot 160}+\mathrm{cpx}_{0} \cdot 880+\mathrm{gt}_{0} \cdot 090$, respectively; Walter, 1998). Mineral/matrix partition coefficients and DMM are from the compilation of [88,89]; PM, N-MORB and E-MORB compositions are from [90]. The heavy line represents the mantle array defined using DMM and PM compositions. Dashed and solid curves (or lines) are the melting trends from DMM. Thick marks on each curve (or line) correspond to degrees of partial melting for a given mantle source.

\subsection{Fractional Crystallization}

The major element trends are a reflection of the modifications taking place during differentiation. The trend for the dyke swarm shows the classical hallmarks of crystal fractionation, with inflections in the Harker diagrams for the positive trend of $\mathrm{FeO}_{\mathrm{t}}, \mathrm{P}_{2} \mathrm{O}_{5}$, $\mathrm{TiO}_{2}$ and $\mathrm{CaO}$ (Figure 7). $\mathrm{CaO}$ decreased equally for all samples, when using decreasing $\mathrm{MgO}$ as a differentiation index, suggesting that the melts experienced some plagioclase, clinopyroxene and presumably olivine fractionation. Fractionation trends based on $\mathrm{MgO}$, $\mathrm{Al}_{2} \mathrm{O}_{3}$ and $\mathrm{CaO}$ are supported by decreasing $\mathrm{Cr}, \mathrm{Ni}$, Sc and $\mathrm{Co}$, which typically partition into olivine and clinopyroxene. Fe-Ti oxide is observed as a phenocryst phase with $\mathrm{SiO}_{2}$ contents below $48 \%$, so the depletion in $\mathrm{TiO}_{2}$ and $\mathrm{P}_{2} \mathrm{O}_{5}$ may be caused by the earlier onset of Ti-bearing magnetite and apatite fractionation. This can be caused by a high concentration of water in the magma, as this depresses the liquid temperatures of the silicates more than that of non-silicate minerals [108,109], although the fractionation of amphibole may also help to deplete the residual liquids in iron [110]. On the other hand, the $\mathrm{Th} / \mathrm{Nb} \mathrm{vs} . \mathrm{Ta} / \mathrm{Yb}$ diagram of Pearce (1982) shows the effects of fractional crystallization (FC) and assimilationfractional crystallization (AFC) processes on magma evolution (Figure 13). These ratios are almost independent of fractional crystallization and/or partial melting (with pyroxenes and feldspars as the dominant crystallizing or residual phases), and thus highlight source variations and crustal assimilation. Basaltic magmas derived from the mantle asthenosphere (depleted MORB mantle; DMM), plume asthenosphere or mantle lithosphere are enriched by small degree melts from the asthenosphere, and all lie within or close to a diagonal mantle array defined by constant Th/Ta ratios. Source region metasomatism caused by subduction processes, however, results in an enrichment of Th with respect to Ta and, hence, in $\mathrm{Th} / \mathrm{Yb}$ ratios higher than $\mathrm{Ta} / \mathrm{Yb}$, as subduction components in general carry $\mathrm{Th}$, but not $\mathrm{Ta}$ or $\mathrm{Yb}$. Crustal contamination may also increase $\mathrm{Th} / \mathrm{Yb}$ ratios relative to $\mathrm{Ta} / \mathrm{Yb}$ ratios because of higher abundances of Th relative to Ta in the crustal rocks (except for the granulite facies crust, which has low Th contents). Figure 13 shows that all rocks are displaced to high $\mathrm{Th} / \mathrm{Yb}$ ratios relative to the mantle array. Although the effects of crustal contamination on magma compositions are difficult to distinguish from those of metasomatism caused by subduction processes, the significantly high $\mathrm{Th} / \mathrm{Yb}$ ratio for the most basic sample rocks is unlikely to be explained solely by crustal contamination. We have used a Sm-Rb log-log bivariate diagram to evaluate the variations in trace element concentrations within the shoshonitic series (Figure 14). We use $\mathrm{Rb}$ as a fractionation index because it is highly incompatible throughout differentiation, and Sm, because its higher KD for amphibole/liquid compared with pyroxene/liquid separates hydrous from anhydrous crystallization assemblages (Table 4). Theoretical crystallization linear trends are also shown on this plot for specific mineral or relevant mineral assemblages. The data generally follow one trend. The Sm content of the dyke swarm rocks exhibit a positive correlation with the $\mathrm{Rb}$ content, which can be explained by plagioclase, clinopyroxene and olivine crystallization according to the theoretical Rayleigh vectors. The theoretical vector 
calculated using the average mineral assemblage of dyke swarm rocks (Plg 15\% + Cpx 60\%

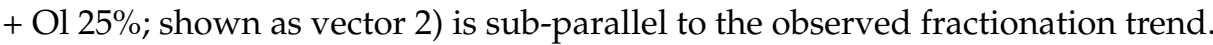

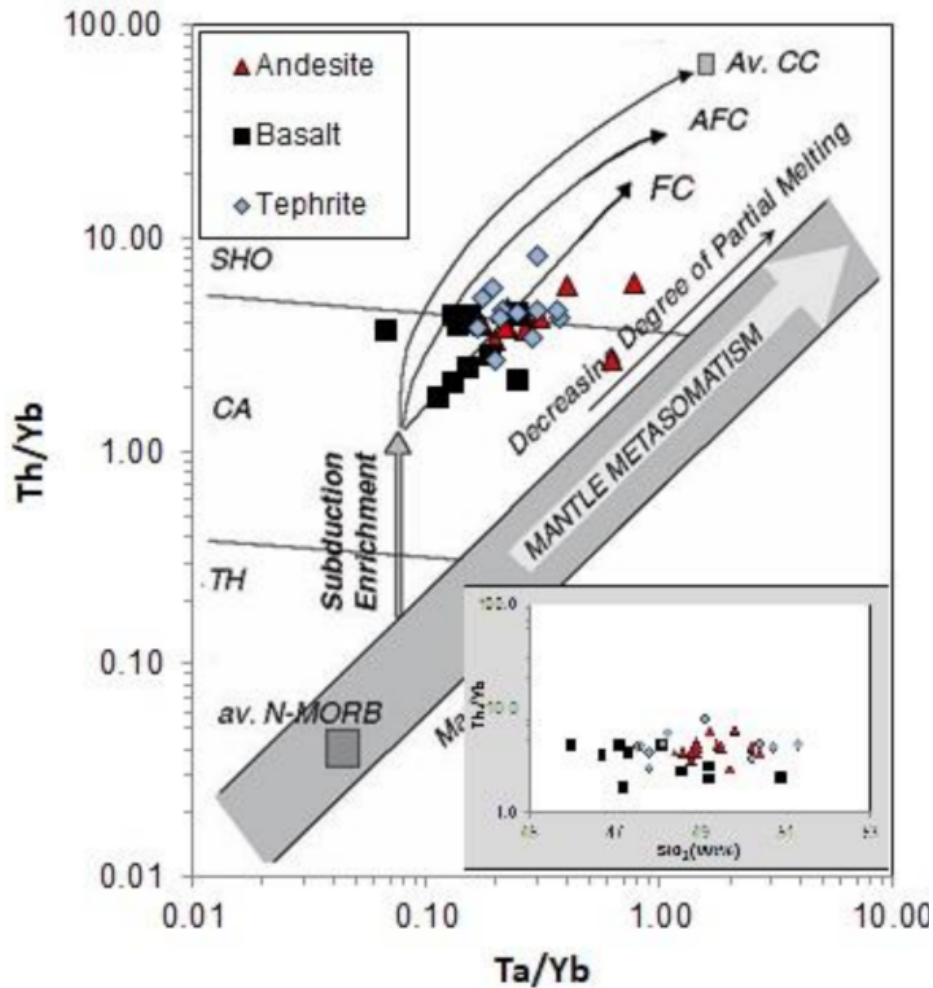

Figure 13. $\mathrm{Th} / \mathrm{Yb}$ against $\mathrm{Ta} / \mathrm{Yb}$ log-log diagram [111] for dyke swarm rocks from northwest of Iran. Shoshonitic rocks exhibit a consistent displacement from the mantle array indicating subductionrelated metasomatism and/or crustal contamination. The inset diagram shows the variations of $\mathrm{Th} / \mathrm{Yb}$ with changing silica contents of the rocks.

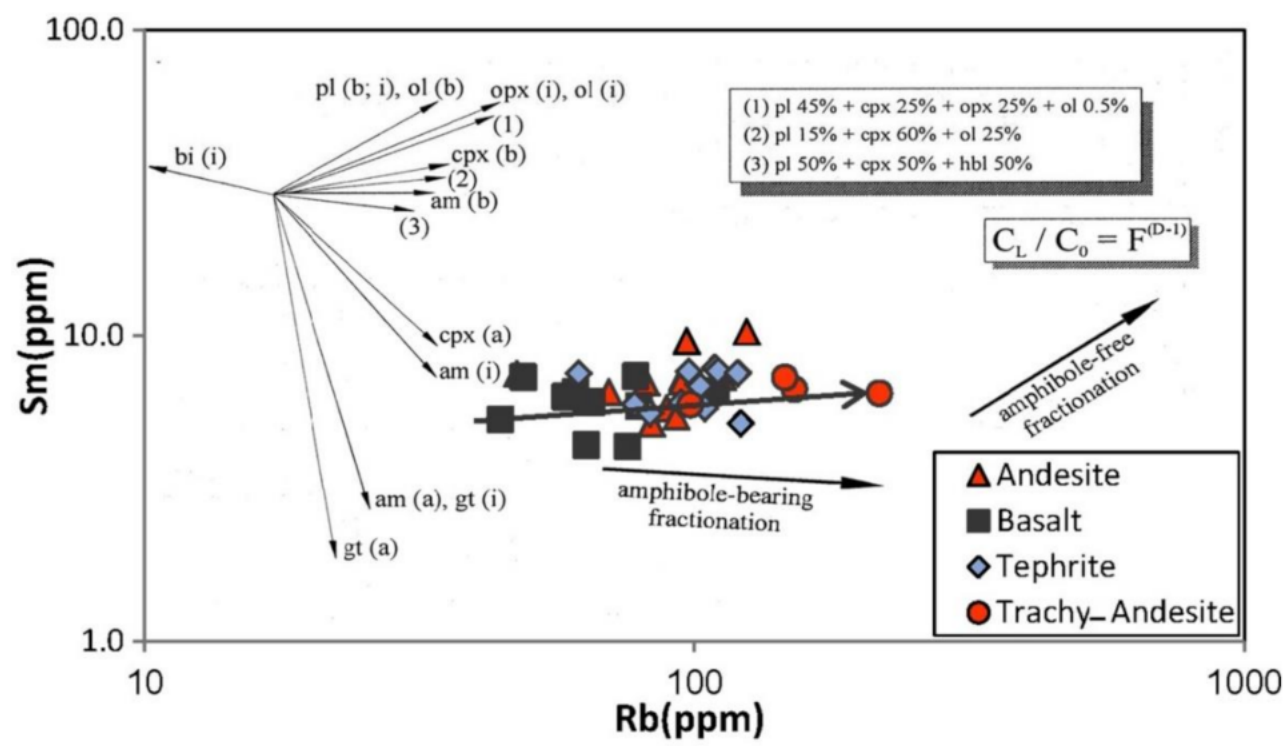

Figure 14. Sm against $\mathrm{Rb} \log$-log diagram showing theoretical fractionation vectors modelled for crystallization of individual mineral phases and phase assemblages. Phase combinations are presented in inset. Theoretical vectors are for $50 \%$ crystallization of single phases and phase combinations. Partition coefficients used for the modelling are from [93]. Key to abbreviations: Am: amphibole, Ol: olivine, Cpx: clinopyroxene, opx: orthopyroxene, Pl: plagioclase, bi: biotite, gt: garnet; b: basic; i: intermediate; a: acid. 
Table 4. Partition coefficients used in FC, AFC and melting models $[77,96]$.

\begin{tabular}{cccccccc}
\hline Elements & Olivine & Opx & Cpx & Garnet & Amphibole & Biotite & Plagioclase \\
\hline $\mathrm{Sm}$ & 0.0013 & 0.01 & 0.283 & 0.217 & 0.85 & 0.03 & 0.11 \\
$\mathrm{Rb}$ & 0.002 & 0.003 & 0.0047 & 0.042 & 0.1 & 5.18 & 0.1 \\
$\mathrm{Th}$ & 0.04 & 0.13 & 0.03 & & 0.05 & 0.0145 & 0.01 \\
$\mathrm{Ta}$ & 0.000018 & 0.15 & 0.013 & 0.06 & 0.25 & 0.1069 & 0.04 \\
$\mathrm{La}$ & 0.00064 & 0.002 & 0.0435 & 0.01 & 0.2 & 0.035 & 0.067 \\
$\mathrm{Yb}$ & 0.14 & 0.34 & 0.512 & & & & \\
\hline
\end{tabular}

\subsection{Geodynamic Implications}

The origin and evolution of magmatic rocks along convergent plate margins involve a series of processes [112], including the metasomatism of the mantle wedge by melt and/or fluids released by the down-going slab $[60,113,114]$, the variable degree of partial melting of the metasomatized mantle [115] and the subsequent processes at shallower depths, such as magma mixing, assimilation, fractionation, contamination [116] and/or combinations of these processes $[77,96]$. The Meshkinshahr dyke swarm rocks are characterized by a fractionated REE pattern, with a high LREE/HREE ratio, resembling shoshonitic rocks from active continental margins and/or post-collisional magmatism after the closure of oceanic basins. The depletion in high field strength elements and enrichment in large lithophile elements are conspicuous. Such shoshonitic volcanism is characteristic of the Turkish-Iranian high plateau. The interaction with crustal rocks and/or derivation from a subduction-contaminated source is also clear from the $\mathrm{Th} / \mathrm{Yb}$ versus $\mathrm{Ta} / \mathrm{Yb}$ diagram [117]. In this diagram, the studied dykes showed a higher $\mathrm{Th} / \mathrm{Yb}$ ratio far from within plate mantle trend, resembling the lava that erupted above an active continental margin (Figure 15a). Higher Th content could have also resulted from the interaction of ascending lava with crustal rocks, via assimilation-fractional crystallization (AFC) processes. The dyke swarm rocks developed in active continental margins, as shown by the $\mathrm{Ta} / \mathrm{Yb}$ versus $\mathrm{Th} / \mathrm{Yb}$ diagram of [118] (Figure 15a). The studied samples show an island arc lava characterization in the Zr versus Ti diagram [60] (Figure 15b). The investigated dyke samples in $\mathrm{Zr} / \mathrm{Y}$ versus $\mathrm{Nb} / \mathrm{Y}$ and $\mathrm{Nb} / \mathrm{Th}$ versus $\mathrm{Zr} / \mathrm{Nb}$ diagrams [119] form an island arc tectonic setting field (Figure 14). These observations and isotopic characteristics of the lava suggest that their magmas were probably derived from the partial melting of a subduction-metasomatized continental lithospheric mantle in the garnet/spinel lherzolite field [25]. This caused localized upwelling in the metasomatized mantle wedge, leading to partial melting that formed the Tertiary magmatism of the Urmia-Dokhtar and Alborz-Azerbaijan zones. Due to subduction, the Neotethys Ocean closing and the post-collision processes, several porphyry copper deposits were formed [120,121]. Eocene to Oligo-Miocene lava and associated plutonic rocks with high-K calc-alkaline or potassic affinities occur only in Armenia and the northwest of Iran [122-124]. Widespread volcanism across the Turkish-Iranian plateau throughout the Late Cenozoic until the Plio-Quaternary is strictly ascribed to post-collisional mantle upwelling during slab steeping and break-off beneath a subduction-accretion complex $[33,125]$. We suggest that slab break-off is an effective mechanism for heating and causes the partial melting of subduction, changing the sub-continental mantle and generating mafic shoshonitic magma in the Urumieh-Dokhtar magmatic belt and in Ahar-Arasbaran and Central Iran. Following the detachment of the subducting oceanic slab, the negative buoyancy of the under-plated Arabian crust and the asthenospheric upwelling generated the rapid post-collisional uplift of the accreted Iranian microplate. This uplift, in turn, led to in-crustal exhumation, tectonic extension and the formation of a core complex in the crystalline basement rocks in the region [126-128]. The tectonic extension is accompanied by crustal thinning, normal fault generation and a swarm dyke propagation setting, which facilitated the rapid ascent of magma to the crustal level with low contamination in the Meshkinshahr area, NW Iran. 

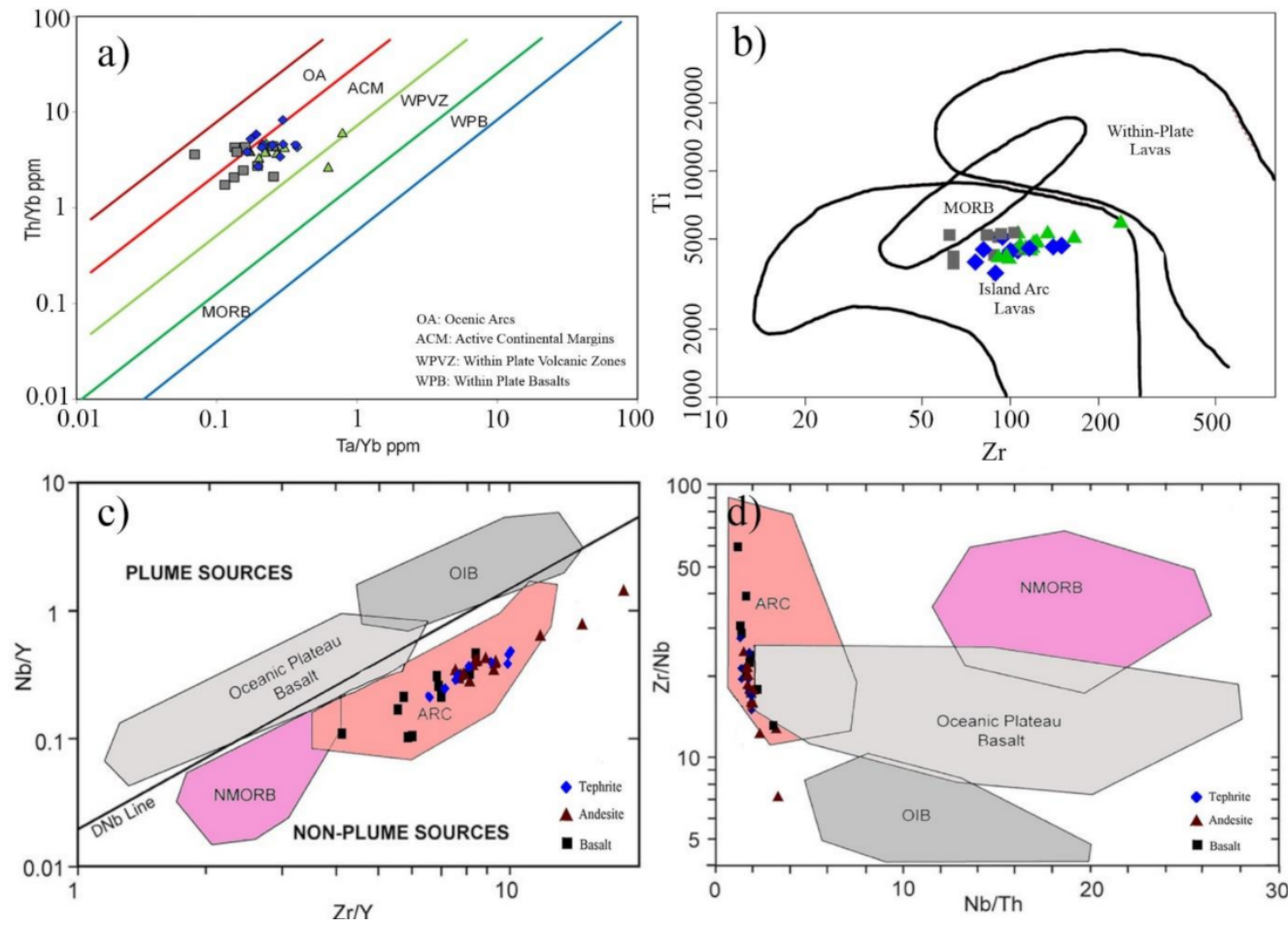

Figure 15. (a) Ta/Yb versus Th/Yb diagram [118], (b) Zr versus Ti diagram [60], (c) Zr/Y versus $\mathrm{Nb} / \mathrm{Y}$ diagram [119] and (d) $\mathrm{Nb} / \mathrm{Th}$ versus $\mathrm{Zr} / \mathrm{Nb}$ diagram [119].

\section{Conclusions}

Shoshonitic mafic dyke swarms with a basalt, tephrite to andesitic composition were developed during the Eocene in NE Meshkinshahr, NW Iran.

Geochemically, the studied samples show a compositional range from 44.8 to $59.6 \mathrm{wt}$ \% $\mathrm{SiO}_{2}$, with high $\mathrm{K}_{2} \mathrm{O}$, similar trace elements and $\mathrm{REE}$ patterns, strong enrichments in $\mathrm{Rb}$, $\mathrm{Ba}$, Th and $\mathrm{La}$ and troughs in $\mathrm{Nb}$, Ta and $\mathrm{Zr}$ relative to primitive mantle, indicating a subduction-modified lithospheric mantle.

The initial ${ }^{143} \mathrm{Nd} /{ }^{144} \mathrm{Nd}$ and ${ }^{87} \mathrm{Sr} /{ }^{86} \mathrm{Sr}$ ratios of studied volcanic rocks were plotted in the mantle array field with slightly enriched sources, supporting the idea that the metasomatized lithospheric mantle was the source, generating subduction-related fluids.

Continental collision between Arabia and Eurasia led to slab break-off and the development of an asthenospheric window, facilitating the partial melting of the subductioncontaminated sub-continental lithospheric mantle, resulting in the production of mafic alkaline potassic magma.

The slab break-off was followed by crustal thinning, tectonic extension, normal fault generation and a swarm dyke propagation setting, which facilitated rapid ascent of the magma to the crustal level in the Meshkinshahr area, NW Iran.

Author Contributions: Conceptualization, M.F., A.J., S.A. and A.A.K.; methodology, M.F., A.J., S.A., W.X., and A.A.K.; field investigation, M.F., A.J. and A.A.K.; data curation, M.F., A.J., S.A., W.X. and A.A.K.; writing - original draft preparation, M.F., A.J., S.A. and A.A.K.; writing-review and editing, M.F. and A.A.K.; supervision, M.F., A.J., S.A., and W.X.; funding acquisition, M.F., A.J., S.A., W.X. and A.A.K. All authors have read and agreed to the published version of the manuscript.

Funding: This study was financially supported by the National Natural Science Foundation of China ( 41822204 and 41888101).

Data Availability Statement: Not Applicable.

Acknowledgments: The first author (HSM) thanks Y. Ersoy for providing him with the latest version of FC-AFC-FCA and mixing modeler software. 
Conflicts of Interest: The authors declare no conflict of interest.

\section{References}

1. Bleeker, W.; Ernst, R. Short-lived mantle generated magmatic events and their dyke swarms: The key unlocking Earth's paleogeographic record back to 2.6 Ga. In Dyke Swarms-Time Markers of Crustal Evolution, Proceedings of the Fifth International Conference, IDC-5, Rovaniemi, Finland, 31 July-3 August 2005; Hanski, E., Mertanen, S., Rämö, T., Vuollo, J., Eds.; Taylor \& Francis: Boca Raton, FL, USA, 2006; pp. 1-24. ISBN 0-415-39899-1.

2. Halls, H.C. The Importance and Potential of Mafic Dyke Swarms in Studies of Geodynamic Processes. Geosci. Can. 1982, 9, 3.

3. Srivastava, R.K. Dyke Swarms: Keys for Geodynamic Interpretation; Springer: Berlin/Heidelberg, Germany, 2011. [CrossRef]

4. Joplin, G.A. The problem of the potash-rich basaltic rocks. Miner. Mag. J. Miner. Soc. 1965, 34, 266-275. [CrossRef]

5. Keller, J. Petrology of some volcanic rock series of the Aeolian arc, Southern Tyrrhenian Sea: Calc-alkaline and shoshonitic associations. Contrib. Miner. Pet. 1974, 46, 29-47. [CrossRef]

6. Peccerillo, A.; Taylor, S.R. Geochemistry of eocene calc-alkaline volcanic rocks from the Kastamonu area, Northern Turkey. Contrib. Miner. Petrol. 1976, 58, 63-81. [CrossRef]

7. Morrison, G.W. Characteristics and tectonic setting of the shoshonite rock association. Lithos 1980, 13, 97-108. [CrossRef]

8. Peccerillo, A. Potassic and ultrapotassic rocks: Compositional characteristics, petrogenesis, and geologic significance. Episodes 1992, 15, 243-251. [CrossRef]

9. Müller, D.; Groves, D.I. Potassic Igneous Rocks and Associated Gold-Copper Mineralization, 3rd ed.; Springer: Berlin/Heidelberg, Germany, 1997.

10. Campbell, I.H.; Stepanov, A.S.; Liang, H.-Y.; Allen, C.M.; Norman, M.; Zhang, Y.-Q.; Xie, Y.-W. The origin of shoshonites: New insights from the Tertiary high-potassium intrusions of eastern Tibet. Contrib. Miner. Pet. 2014, 167, 1-22. [CrossRef]

11. Jiang, Y.-H.; Jiang, S.-Y.; Ling, H.-F.; Zhou, X.-R.; Rui, X.-J.; Yang, W.-Z. Petrology and geochemistry of shoshonitic plutons from the western Kunlun orogenic belt, Xinjiang, northwestern China: Implications for granitoid geneses. Lithos 2002, 63, 165-187. [CrossRef]

12. Küster, D.; Harms, U. Post-collisional potassic granitoids from the southern and northwestern parts of the Late Neoproterozoic East African Orogen: A review. Lithos 1998, 45, 177-195. [CrossRef]

13. Wyllie, P.J.; Sekine, T. The formation of mantle phlogopite in subduction zone hybridization. Contrib. Miner. Pet. 1982, 79, 375-380. [CrossRef]

14. Topuz, G.; Okay, A.; Altherr, R.; Schwarz, W.H.; Siebel, W.; Zack, T.; Satır, M.; Şen, C. Post-collisional adakite-like magmatism in the Ağvanis Massif and implications for the evolution of the Eocene magmatism in the Eastern Pontides (NE Turkey). Lithos 2011, 125, 131-150. [CrossRef]

15. Stocklin, J. Structural History and Tectonics of Iran: A Review. AAPG Bull. 1968, 52, 1229-1258. [CrossRef]

16. Berberian, M.; King, G.C.P. Towards a paleogeography and tectonic evolution of Iran. Can. J. Earth Sci. 1981, 18, 210-265. [CrossRef]

17. McQuarrie, N.; Stock, J.M.; Verdel, C.; Wernicke, B.P. Cenozoic evolution of Neotethys and implications for the causes of plate motions. Geophys. Res. Lett. 2003, 30, 20. [CrossRef]

18. Şengör, A.M.C. A new model for the late Palaeozoic-Mesozoic tectonic evolution of Iran and implications for Oman. Geol. Soc. London Spéc. Publ. 1990, 49, 797-831. [CrossRef]

19. Amidi, S.M.; Emami, M.H.; Michel, R. Alkaline character of Eocene volcanism in the middle part of central Iran and its geodynamic situation. Geol. Rundsch. 1984, 73, 917-932. [CrossRef]

20. Verdel, C.; Wernicke, B.P.; Hassanzadeh, J.; Guest, B. A Paleogene extensional arc flare-up in Iran. Tectonics 2011, 30, 1-20. [CrossRef]

21. Agard, P.; Omrani, J.; Jolivet, L.; Whitechurch, H.; Vrielynck, B.; Spakman, W.; Monié, P.; Meyer, B.; Wortel, R. Zagros orogeny: A subduction-dominated process. Geol. Mag. 2011, 148, 692-725. [CrossRef]

22. Aftabi, A.; Atapour, H. Regional aspects of shoshonitic volcanism in Iran. Episodes 2000, 23, 119-125.

23. Alberti, A.; Comin-Chiaramonti, P.; Di Battistini, G.; Fioriti, R.; Sinigei, S. Crystal Fractionation in the eastern Azerbaijan (Iran) Lower Tertiary shoshonitic suite. Neues Jahrbuch für Mineral. Monatshefte 1981, 1, 35-48.

24. Comin-Chiaramonti, P.; Meriani, S.; Mosca, R.; Sinigoi, S. On the occurrence of analcime in the northeastern Azerbaijan volcanics (northwestern Iran). Lithos 1979, 12, 187-198. [CrossRef]

25. Dilek, Y.; Imamverdiyev, N.; Şafak, A. Geochemistry and tectonics of Cenozoic volcanism in the Lesser Caucasus (Azerbaijan) and the peri-Arabian region: Collision-induced mantle dynamics and its magmatic fingerprint. Int. Geol. Rev. 2009, 52, 536-578. [CrossRef]

26. Haghipour, A.; Aghanabati, A. Geological Map of Iran (Scale 1:2,500,000); Geological Survey of Iran: Tehran, Iran, 1985.

27. Lescuyer, J.L.; Riou, R. Géologie de la Région de Mianeh (Azerbaijan): Contribution à L'étude du Volcanisme Tertiaire de L'Iran; Université Scientifique et Médicale de Grenoble: Grenoble, France, 1976.

28. Lotfi, M. Geology and Petrology of Mianeh, Azerbaijan Area; Tehran University: Tehran, Iran, 1975.

29. Sauter, D.; Cannat, M.; Rouméjon, S.; Andreani, M.; Birot, D.; Bronner, A.; Brunelli, D.; Carlut, J.; Delacour, A.; Guyader, V.; et al. Continuous exhumation of mantle-derived rocks at the Southwest Indian Ridge for 11 million years. Nat. Geosci. 2013, 6, 314-320. [CrossRef] 
30. Whitechurch, H.; Omrani, J.; Agard, P.; Humbert, F.; Montigny, R.; Jolivet, L. Evidence for Paleocene-Eocene evolution of the foot of the Eurasian margin (Kermanshah ophiolite, SW Iran) from back-arc to arc: Implications for regional geodynamics and obduction. Lithos 2013, 182-183, 11-32. [CrossRef]

31. Dhont, D.; Chorowicz, J. Review of the neotectonics of the Eastern Turkish-Armenian Plateau by geomorphic analysis of digital elevation model imagery. Geol. Rundsch. 2005, 95, 34-49. [CrossRef]

32. Dilek, Y.; Şafak, A. Geochemical and temporal evolution of Cenozoic magmatism in western Turkey: Mantle response to collision, slab break-off, and lithospheric tearing in an orogenic belt. Geol. Soc. Lond. Spéc. Publ. 2009, 311, 213-233. [CrossRef]

33. Keskin, M. Magma generation by slab steepening and breakoff beneath a subduction-accretion complex: An alternative model for collision-related volcanism in Eastern Anatolia, Turkey. Geophys. Res. Lett. 2003, 30, 7-10. [CrossRef]

34. Kheirkhah, M.; Allen, M.; Emami, M. Quaternary syn-collision magmatism from the Iran/Turkey borderlands. J. Volcanol. Geotherm. Res. 2009, 182, 1-12. [CrossRef]

35. Pearce, J.; Bender, J.; de Long, S.; Kidd, W.; Low, P.; Güner, Y.; Saroglu, F.; Yilmaz, Y.; Moorbath, S.; Mitchell, J. Genesis of collision volcanism in Eastern Anatolia, Turkey. J. Volcanol. Geotherm. Res. 1990, 44, 189-229. [CrossRef]

36. Riou, R.; Dupuy, C.; Dostal, J. Geochemistry of coexisting alkaline and calc-alkaline volcanic rocks from northern Azerbaijan (N.W. Iran). J. Volcanol. Geotherm. Res. 1981, 11, 253-275. [CrossRef]

37. Göçmengil, G.; Karacik, Z.; Genç, Ş.C.; Billor, M.Z. 40Ar-39Ar geochronology and petrogenesis of postcollisional trachytic volcanism along the İzmir-Ankara-Erzincan Suture Zone (NE, Turkey)*. Turk. J. Earth Sci. 2018, 27, 1-31. [CrossRef]

38. Emami, M.H. Geologie de la Region de Qom. Aran (Iran) Contribution an I'etude Dynamique Etgeochemique du Volcanisme Tertiaire I'Iran Central. Earth Grenoble 1981, 21, 489.

39. Ghasemi-Barghi, A.; Vosoughi-Abedini, M.; Pourmoafee, M. Petrography, Geochemistry and geodynamic of moradloo dikes, Northwest of Ardebil (NW Iran). Geosciences 2006, 16, 92-107.

40. Hassanzadeh, J. Metallogenic and Tectonomagmatic Events in the SE Sector of Cenozoic Active Continental Margin of Central Iran (Shahr-e Babak Area, Kerman Province); University of California: Los Angeles, CA, USA, 1993.

41. Moradian, A. Petrological and Economical Evaluation of Feldspathoidal Rocks of Northern Shahr-e Babak, Kerman. Master's Thesis, Tehran University, Tehran, Iran, 1990.

42. Aftabi, A.; Atapour, H. Geochemical and petrological characteristics of shoshonitic and potassic calcalkaline magmatism at Sarcheshmeh and Dehsiahan porphyry copper deposits, Kerman, Iran. Res. Bull. Isfahan Univ. 1997, 9, $127-156$.

43. Atapour, H. Petrology and Geochemistry of Shoshonitic Association of Goud-e-Biabani Bardsir Area, Kerman Province. Master's Thesis, Shahid Bahonar University of Kerman, Kerman, Iran, 1994. (In Persian).

44. Fadaeian, M.; Jahangiri, A.; Moayyed, M. Mineral chemistry, thermobarometry and genesis of Clinopyroxenes in dyke swarm of northeast of meshkinshahr, NW Iran. Journal of Geoscience 2016, 25, 19-36. [CrossRef]

45. Stöcklin, J. Structural Correlation of the Alpine Ranges between Iran and Central Asia; Memoire Hors Serie; Societe Geologique de France: Paris, France, 1977; Volume 8, pp. 333-353.

46. Nabavi, M.H. An introduction to the geology of Iran. Geol. Surv. Iran 1976, 109.

47. Nezafati, N. Au-Sn-W-Cu-Mineralization in the Astaneh-Sarband Area, West Central Iran including a Comparison of the Ores with Ancient Bronze Artifacts from Western Asia. Ph.D. Thesis, University of Freiberg, Freiberg, Germany, 2006.

48. Alberti, A.A.; Comin-Chiaramonti, P.; Sinigoi, S.; Nicoletti, M.; Petrucciani, C. Neogene and quaternary volcanism in Eastern Azerbaijan (Iran): Some K-Ar age determinations and geodynamic implications. Geol. Rundsch. 1980, 69, 216-225. [CrossRef]

49. Didon, J.; Germain, Y.M. Le Sabalan, Volcan Plio-quaternaire de l'Azerbaidjan Oriental (Iran): Étude Géologique et Pétrographique de L'édifice et de son Environnement Régional. Doctoral Dissertation, Universite Scientifique et Médicale de Grenoble, Grenoble, France, 1976.

50. Babakhani, A.; Khan-Nazar, H. Geological Map of Lahrud Area (1:100000); Geological Survey of Iran: Tehran, Iran, 1991.

51. Alberti, A.; Battistini, G.; Nicoletti, M.; Petruciani, C.; Sinigoi, S. Geochronology of the Eastern Azerbaijan volcanic plateau (northwest Iran). Rend. Soc. Ital. Min. Petrol. 1976, 32, 579-589.

52. Li, C.-F.; Li, X.-H.; Li, Q.-L.; Guo, J.-H.; Li, X.-H.; Feng, L.-J.; Chu, Z.-Y. Simultaneous Determination of $143 \mathrm{Nd} / 144 \mathrm{Nd}$ and $147 \mathrm{Sm} / 144 \mathrm{Nd}$ Ratios and Sm-Nd Contents from the Same Filament Loaded with Purified Sm-Nd Aliquot from Geological Samples by Isotope Dilution Thermal Ionization Mass Spectrometry. Anal. Chem. 2012, 84, 6040-6047. [CrossRef]

53. Li, C.-F.; Li, X.-H.; Li, Q.; Guo, J.-H.; Li, X.-H.; Yang, Y.-H. Rapid and precise determination of Sr and Nd isotopic ratios in geological samples from the same filament loading by thermal ionization mass spectrometry employing a single-step separation scheme. Anal. Chim. Acta 2012, 727, 54-60. [CrossRef]

54. Xie, L.; Zhang, Y.; Zhang, H.; Sun, J.; Wu, F. In situ simultaneous determination of trace elements, U-Pb and Lu-Hf isotopes in zircon and baddeleyite. Sci. Bull. 2008, 53, 1565-1573. [CrossRef]

55. Andersen, T. Correction of common lead in U-Pb analyses that do not report 204Pb. Chem. Geol. 2002, 192, 59-79. [CrossRef]

56. Ludwig, K.R. User's Manual for Isoplot 3.00: A Geochronological Toolkit for Microsoft Excel; Berkeley Geochronology Center Special Publication; Berkeley Geochronology Center: Berkeley, CA, USA; pp. 238-249.

57. Whitney, D.; Evans, B.W. Abbreviations for names of rock-forming minerals. Am. Miner. 2009, 95, 185-187. [CrossRef]

58. Middlemost, E.A.K. Naming materials in the magma/igneous rock system. Earth-Sci. Rev. 1994, 37, 215-224. [CrossRef]

59. Hastie, A.R.; Kerr, A.C.; Pearce, J.A.; Mitchell, S. Classification of Altered Volcanic Island Arc Rocks using Immobile Trace Elements: Development of the Th-Co Discrimination Diagram. J. Pet. 2007, 48, 2341-2357. [CrossRef] 
60. Pearce, J.A. Trace element characteristics of lavas from destructive plate boundaries. In Andesites: Orogenic Andesites and Related Rocks; John Wiley and Sons: Hoboken, NJ, USA, 1982.

61. Pearce, J.A.; Cann, J.R. Tectonic setting of basic volcanic rocks determined using trace element analyses. Earth Planet. Sci. Lett. 1973, 19, 290-300. [CrossRef]

62. Pearce, J.A.; Peate, D.W. Tectonic Implications of the Composition of Volcanic ARC Magmas. Ann. Rev. Earth Planet. Sci. 1995, 23, 251-285. [CrossRef]

63. Hofmann, A.W.; Jochum, K.P. Source characteristics derived from very incompatible trace elements in Mauna Loa and Mauna Kea basalts, Hawaii Scientific Drilling Project. J. Geophys. Res. Earth Surf. 1996, 101, 11831-11839. [CrossRef]

64. Zhang, Z.; Xiao, X.; Wang, J.; Wang, Y.; Kusky, T.M. Post-collisional Plio-Pleistocene shoshonitic volcanism in the western Kunlun Mountains, NW China: Geochemical constraints on mantle source characteristics and petrogenesis. J. Southeast Asian Earth Sci. 2008, 31, 379-403. [CrossRef]

65. McDonough, W.F.; Sun, S.-S. The composition of the Earth. Chem. Geol. 1995, 120, 223-253. [CrossRef]

66. Liew, T.C.; Hofmann, A.W. Precambrian crustal components, plutonic associations, plate environment of the Hercynian Fold Belt of central Europe: Indications from a Nd and Sr isotopic study. Contrib. Miner. Pet. 1988, 98, 129-138. [CrossRef]

67. Elitok, Ö.; Özgür, N.; Drüppel, K.; Dilek, Y.; Platevoet, B.; Guillou, H.; Poisson, A.; Scaillet, S.; Satır, M.; Siebel, W.; et al. Origin and geodynamic evolution of late Cenozoic potassium-rich volcanism in the Isparta area, southwestern Turkey. Int. Geol. Rev. 2009, 52, 454-504. [CrossRef]

68. Eyuboglu, Y. Late Cretaceous high-K volcanism in the eastern Pontide orogenic belt: Implications for the geodynamic evolution of NE Turkey. Int. Geol. Rev. 2009, 52, 142-186. [CrossRef]

69. Lu, Y.-J.; Kerrich, R.; Cawood, P.A.; McCuaig, T.C.; Hart, C.J.; Li, Z.-X.; Hou, Z.-Q.; Bagas, L. Zircon SHRIMP U-Pb geochronology of potassic felsic intrusions in western Yunnan, SW China: Constraints on the relationship of magmatism to the Jinsha suture. Gondwana Res. 2012, 22, 737-747. [CrossRef]

70. Mitchell, R.; Smith, C.; Vladykin, N. Isotopic composition of strontium and neodymium in potassic rocks of the Little Murun complex, Aldan Shield, Siberia. Lithos 1994, 32, 243-248. [CrossRef]

71. Rock, N.M.S.; Groves, D.I. Geochemical discrimination between shoshonitic and potassic volcanic rocks in different tectonic settings: A pilot study. Miner. Pet. 1992, 46, 259-289. [CrossRef]

72. Aldanmaz, E.; Pearce, J.; Thirlwall, M.; Mitchell, J. Petrogenetic evolution of late Cenozoic, post-collision volcanism in western Anatolia, Turkey. J. Volcanol. Geotherm. Res. 2000, 102, 67-95. [CrossRef]

73. Alıcı, P.; Temel, A.; Gourgaud, A.; Kieffer, G.; Gündoğdu, M. Petrology and geochemistry of potassic rocks in the Gölcük area (Isparta, SW Turkey): Genesis of enriched alkaline magmas. J. Volcanol. Geotherm. Res. 1998, 85, 423-446. [CrossRef]

74. Şafak, A.; Genc, S. Petrogenesis and time-progressive evolution of the Cenozoic continental volcanism in the Biga Peninsula, NW Anatolia (Turkey). Lithos 2008, 102, 316-340. [CrossRef]

75. Şafak, A.; Dilek, Y.; Genc, S.; Sunal, G.; Gertisser, R.; Furnes, H.; Foland, K.A.; Yang, J. Spatial, temporal and geochemical evolution of Oligo-Miocene granitoid magmatism in western Anatolia, Turkey. Gondwana Res. 2012, 21, 961-986. [CrossRef]

76. Ersoy, E.Y.; Helvac1, C.; Uysal, I.; Karaoğlu, Ö.; Palmer, M.R.; Dindi, F. Petrogenesis of the Miocene volcanism along the İzmirBalıkesir Transfer Zone in western Anatolia, Turkey: Implications for origin and evolution of potassic volcanism in post-collisional areas. J. Volcanol. Geotherm. Res. 2012, 241-242, 21-38. [CrossRef]

77. Ersoy, E.Y.; Helvacı, C.; Palmer, M.R. Mantle source characteristics and melting models for the early-middle Miocene mafic volcanism in Western Anatolia: Implications for enrichment processes of mantle lithosphere and origin of K-rich volcanism in post-collisional settings. J. Volcanol. Geotherm. Res. 2010, 198, 112-128. [CrossRef]

78. Kirchenbaur, M.; Münker, C.; Schuth, S.; Marchev, P.; Garbe-Schönberg, D. Tectonomagmatic Constraints on the Sources of Eastern Mediterranean K-rich Lavas. J. Pet. 2011, 53, 27-65. [CrossRef]

79. Gülmez, F.; Genc, S.; Prelević, D.; Tüysüz, O.; Karacik, Z.; Roden, M.F.; Billor, Z. Ultrapotassic Volcanism from the Waning Stage of the Neotethyan Subduction: A Key Study from the Izmir-Ankara-Erzincan Suture Belt, Central Northern Turkey. J. Pet. 2016, 57, 561-593. [CrossRef]

80. Karacık, Z.; Yılmaz, Y.; Pearce, J.A.; Ece, Ö.I. Petrochemistry of the south Marmara granitoids, northwest Anatolia, Turkey. Geol. Rundsch. 2007, 97, 1181-1200. [CrossRef]

81. Ersoy, Y.E.; Helvac1, C.; Palmer, M.R. Petrogenesis of the Neogene volcanic units in the NE-SW-trending basins in western Anatolia, Turkey. Contrib. Miner. Pet. 2012, 163, 379-401. [CrossRef]

82. Moine-Vaziri, H.; Khalili Marandi, S.H.; Brousse, R. Importance doun volcanism potassique, au Miocene Superier, en Azerbaijan, Iran. Comp. R. Acad. Sci. Paris 1991, 313, 1603-1610.

83. Robinson, J.C.; Wood, B.J. The depth of the spinel to garnet transition at the peridotite solidus. Earth Planet. Sci. Lett. 1998, 164, 277-284. [CrossRef]

84. Niu, Y.; Hékinian, R. Spreading-rate dependence of the extent of mantle melting beneath ocean ridges. Nature 1997, 385, 326-329. [CrossRef]

85. McCulloch, M.; Gamble, J. Geochemical and geodynamical constraints on subduction zone magmatism. Earth Planet. Sci. Lett. 1991, 102, 358-374. [CrossRef] 
86. Litasov, K.D.; Foley, S.F.; Litasov, Y.D. Magmatic modification and metasomatism of the subcontinental mantle beneath the Vitim volcanic field (East Siberia): Evidence from trace element data on pyroxenite and peridotite xenoliths from Miocene picrobasalt. Lithos 2000, 54, 83-114. [CrossRef]

87. Shaw, D.M. Trace element fractionation during anatexis. Geochim. Cosmochim. Acta 1970, 34, 237-243. [CrossRef]

88. McKenzie, D.; O’Nions, R.K. Partial Melt Distributions from Inversion of Rare Earth Element Concentrations. J. Pet. 1991, 32, 1021-1091. [CrossRef]

89. McKenzie, D.; O’Nions, R.K. The Source Regions of Ocean Island Basalts. J. Pet. 1995, 36, 133-159. [CrossRef]

90. Sun, S.-s.; McDonough, W.F. Chemical and isotopic systematics of oceanic basalts: Implications for mantle composition and processes. In Geological Society, London, Special Publications; Geological Society of London: London, UK, 1989; Volume 42, pp. 313-345. [CrossRef]

91. Eyuboglu, Y.; Santosh, M.; Yi, K.; Bektaş, O.; Kwon, S. Discovery of Miocene adakitic dacite from the Eastern Pontides Belt (NE Turkey) and a revised geodynamic model for the late Cenozoic evolution of the Eastern Mediterranean region. Lithos 2012, 146-147, 218-232. [CrossRef]

92. Zhilong, H.; Chongqiang, L.; Hailing, Y.; Cheng, X.; Runsheng, H.; Yunhua, X.; Bo, Z.; Wenbo, L. The geochemistry of lamprophyres in the Laowangzhai gold deposits, Yunnan Province, China: Implications for its characteristics of source region. Geochem. J. 2002, 36, 91-112. [CrossRef]

93. Keskin, M.; Pearce, J.; Mitchell, J. Volcano-stratigraphy and geochemistry of collision-related volcanism on the Erzurum-Kars Plateau, northeastern Turkey. J. Volcanol. Geotherm. Res. 1998, 85, 355-404. [CrossRef]

94. Yılmaz, Y.; Güner, Y.; Şaroğlu, F. Geology of the quaternary volcanic centres of the east Anatolia. J. Volcanol. Geotherm. Res. 1998, 85, 173-210. [CrossRef]

95. Conticelli, S.; Avanzinelli, R.; Poli, G.; Braschi, E.; Giordano, G. Shift from lamproite-like to leucititic rocks: Sr-Nd-Pb isotope data from the Monte Cimino volcanic complex vs. the Vico stratovolcano, Central Italy. Chem. Geol. 2013, 353, 246-266. [CrossRef]

96. Ersoy, E.Y.; Helvacı, C. FC-AFC-FCA and mixing modeler: A Microsoft ${ }^{\circledR}$ Excel@ spreadsheet program for modeling geochemical differentiation of magma by crystal fractionation, crustal assimilation and mixing. Comput. Geosci. 2010, 36, 383-390. [CrossRef]

97. Agard, P.; Omrani, J.; Jolivet, L.; Mouthereau, F. Convergence history across Zagros (Iran): Constraints from collisional and earlier deformation. Geol. Rundsch. 2005, 94, 401-419. [CrossRef]

98. Davidson, J.P.; Turner, S.; Plank, T. Dy/Dy*: Variations Arising from Mantle Sources and Petrogenetic Processes. J. Pet. 2012, 54, 525-537. [CrossRef]

99. Sims, K.W.W.; DePaolo, D.J.; Murrell, M.T.; Baldridge, W.S.; Goldstein, S.J.; Clague, D.A. Mechanisms of Magma Generation Beneath Hawaii and Mid-Ocean Ridges: Uranium/Thorium and Samarium/Neodymium Isotopic Evidence. Science 1995, 267, 508-512. [CrossRef] [PubMed]

100. Sims, K.; DePaolo, D.; Murrell, M.; Baldridge, W.; Goldstein, S.; Clague, D.; Jull, M. Porosity of the melting zone and variations in the solid mantle upwelling rate beneath Hawaii: Inferences from 238U-230Th-226Ra and 235U-231Pa disequilibria. Geochim. Cosmochim. Acta 1999, 63, 4119-4138. [CrossRef]

101. Beier, C.; Turner, S.; Plank, T.; White, W. A preliminary assessment of the symmetry of source composition and melting dynamics across the Azores plume. Geochem. Geophys. Geosyst. 2010, 11, 11. [CrossRef]

102. Niu, Y.; Collerson, K.D.; Batiza, R.; Wendt, J.I.; Regelous, M. Origin of enriched-type mid-ocean ridge basalt at ridges far from mantle plumes: The East Pacific Rise at $11^{\circ} 20^{\prime}$ N. J. Geophys. Res. Earth Surf. 1999, 104, 7067-7087. [CrossRef]

103. Regelous, M.; Niu, Y.; Wendt, J.; Batiza, R.; Greig, A.; Collerson, K. Variations in the geochemistry of magmatism on the East Pacific Rise at $10^{\circ} 30^{\prime} \mathrm{N}$ since $800 \mathrm{ka}$. Earth Planet. Sci. Lett. 1999, 168, 45-63. [CrossRef]

104. Turner, S.; Beier, C.; Niu, Y.; Cook, C. U-Th-Ra disequilibria and the extent of off-axis volcanism across the East Pacific Rise at $9^{\circ} 30^{\prime} \mathrm{N}, 10^{\circ} 30^{\prime} \mathrm{N}$, and $11^{\circ} 20^{\prime} \mathrm{N}$. Geochem. Geophys. Geosyst. 2011, 12. [CrossRef]

105. Salters, V.J.M.; Stracke, A. Composition of the depleted mantle. Geochem. Geophys. Geosyst. 2004, 5, 5. [CrossRef]

106. Plank, T.; Langmuir, C.H. The chemical composition of subducting sediment and its consequences for the crust and mantle. Chem. Geol. 1998, 145, 325-394. [CrossRef]

107. Kinzler, R.J. Melting of Mantle Peridotite at Pressures Approaching the Spinel to Garnet Transition. Miner. Mag. 1994, 58A, 483-484. [CrossRef]

108. Parat, F.; Holtz, F.; Feig, S.T. Pre-eruptive Conditions of the Huerto Andesite (Fish Canyon System, San Juan Volcanic Field, Colorado): Influence of Volatiles (C-O-H-S) on Phase Equilibria and Mineral Composition. J. Pet. 2008, 49, 911-935. [CrossRef]

109. Sisson, T.W.; Grove, T.L. Temperatures and $\mathrm{H} 2 \mathrm{O}$ contents of low-MgO high-alumina basalts. Contrib. Miner. Pet. 1993, 113, 167-184. [CrossRef]

110. Alonso-Perez, R.; Müntener, O.; Ulmer, P. Igneous garnet and amphibole fractionation in the roots of island arcs: Experimental constraints on andesitic liquids. Contrib. Miner. Pet. 2009, 157, 541-558. [CrossRef]

111. Pearce, J.A. Role of the Sub-Continental Lithosphere in Magma Genesis at Active Continental Margins. In Continental Basalts and Mantle Xenoliths; Hawkesworth, C.J., Norry, M.J., Eds.; Shiva Publications: Cheshire, UK, 1983; pp. $230-249$.

112. Eyuboglu, Y. Slab window magmatism and convergent margin tectonics. Geosci. Front. 2013, 4, 349-351. [CrossRef]

113. Hawkesworth, C.J.; Hergt, J.; Ellam, R.M.; McDermott, F. Element fluxes associated with subduction related magmatism. Philos. Trans. R. Soc. Lond. Ser. A Phys. Eng. Sci. 1991, 335, 393-405. [CrossRef] 
114. Khedr, M.Z.; Arai, S.; Tamura, A.; Morishita, T. Clinopyroxenes in high-P metaperidotites from Happo-O'ne, central Japan: Implications for wedge-transversal chemical change of slab-derived fluids. Lithos 2010, 119, 439-456. [CrossRef]

115. Pearce, J.A.; Parkinson, I.J. Trace element models for mantle melting: Application to volcanic arc petrogenesis. Geol. Soc. London, Spéc. Publ. 1993, 76, 373-403. [CrossRef]

116. DePaolo, D.J. Trace element and isotopic effects of combined wallrock assimilation and fractional crystallization. Earth Planet. Sci. Lett. 1981, 53, 189-202. [CrossRef]

117. Gorton, M.P.; Schandl, E.S. From Continents to Island Arcs: A Geochemical Index of Tectonic Setting for Arc-Related and Within-Plate Felsic to Intermediate Volcanic Rocks. Can. Miner. 2000, 38, 1065-1073. [CrossRef]

118. Schandl, E.S.; Gorton, M.P. Application of High Field Strength Elements to Discriminate Tectonic Settings in Vms Environments. Econ. Geol. 2002, 97, 629-642. [CrossRef]

119. Condie, K.C. High field strength element ratios in Archean basalts: A window to evolving sources of mantle plumes? Lithos 2005, 79, 491-504. [CrossRef]

120. Moayyed, M. Petrologic Studies of Tertiary Volcano-Plutonic Belt in Western Alborz-Azerbaijan, with a Special Focus on Hashtchin Area, Iran. Ph.D. Thesis, Shahid Beheshti University, Tehran, Iran, 2001.

121. Kamali, A.A.; Moayyed, M.; Amel, N.; Hosseinzadeh, M.R.; Mohammadiha, K.; Santos, J.F.; Brenna, M. Post-Mineralization, Cogenetic Magmatism at the Sungun Cu-Mo Porphyry Deposit (Northwest Iran): Protracted Melting and Extraction in an Arc System. Minerals 2018, 8, 588. [CrossRef]

122. Aghazadeh, M.; Castro, A.; Omran, N.R.; Emami, M.H.; Moinvaziri, H.; Badrzadeh, Z. The gabbro (shoshonitic)-monzonitegranodiorite association of Khankandi pluton, Alborz Mountains, NW Iran. J. Southeast Asian Earth Sci. 2010, 38, 199-219. [CrossRef]

123. Castro, A.; Aghazadeh, M.; Badrzadeh, Z.; Chichorro, M. Late Eocene-Oligocene post-collisional monzonitic intrusions from the Alborz magmatic belt, NW Iran. An example of monzonite magma generation from a metasomatized mantle source. Lithos 2013, 180-181, 109-127. [CrossRef]

124. Moritz, R.; Rezeau, H.; Ovtcharova, M.; Tayan, R.; Melkonyan, R.; Hovakimyan, S.; Ramazanov, V.; Selby, D.; Ulianov, A.; Chiaradia, M.; et al. Long-lived, stationary magmatism and pulsed porphyry systems during Tethyan subduction to post-collision evolution in the southernmost Lesser Caucasus, Armenia and Nakhitchevan. Gondwana Res. 2016, 37, 465-503. [CrossRef]

125. Şengör, A.M.C.; Özeren, S.; Genç, T.; Zor, E. East Anatolian high plateau as a mantle-supported, north-south shortened domal structure. Geophys. Res. Lett. 2003, 30, 30. [CrossRef]

126. Möritz, R.; Ghazban, F.; Singer, B.S. Eocene Gold Ore Formation at Muteh, Sanandaj-Sirjan Tectonic Zone, Western Iran: A Result of Late-Stage Extension and Exhumation of Metamorphic Basement Rocks within the Zagros Orogen. Econ. Geol. 2006, 101, 1497-1524. [CrossRef]

127. Verdel, C.; Wernicke, B.P.; Ramezani, J.; Hassanzadeh, J.; Renne, P.R.; Spell, T.L. Geology and thermochronology of Tertiary Cordilleran-style metamorphic core complexes in the Saghand region of central Iran. GSA Bull. 2007, 119, 961-977. [CrossRef]

128. Dilek, Y.; Sandvol, E. Seismic structure, crustal architecture and tectonic evolution of the Anatolian-African Plate Boundary and the Cenozoic Orogenic Belts in the Eastern Mediterranean Region. Geol. Soc. Lond. Spéc. Publ. 2009, 327, 127-160. [CrossRef] 